\title{
A Microsatellite Analysis Used to Identify Global Pathways of Movement of Phytophthora cinnamomi and the Likely Sources of Wildland Infestations in California and Mexico
}

\author{
María Socorro Serrano,1,2 Todd Osmundson,1,3 Alejandra Almaraz-Sánchez,1,4 Peter J. P. Croucher,1 Tedmund Swiecki, ${ }^{1}$ \\ Dionicio Alvarado-Rosales, ${ }^{4}$ and Matteo Garbelotto ${ }^{1, \dagger}$ \\ ${ }^{1}$ Department of Environmental Science, Policy and Management, University of California, Berkeley, CA 94720, U.S.A. \\ 2 Department of Mediterranean Forest Systems, Institute of Natural Resources and Agrobiology of Seville, 41012, Seville, Spain \\ ${ }^{3}$ Department of Biology, University of Wisconsin-La Crosse, 3005 Cowley Hall, La Crosse, WI 54601, U.S.A. \\ ${ }^{4}$ Programa de Fitopatología, Colegio de Postgraduados, 56230 Montecillo, Texcoco, Edo. de México \\ 5 Phytosphere Research, Vacaville, CA 95687, U.S.A. \\ Accepted for publication 30 April 2019.
}

\begin{abstract}
The genetic structure of a sample of isolates of the oomycete plant pathogen Phytophthora cinnamomi from natural and agricultural outbreaks and the long-distance movement of individual genotypes were studied using four microsatellite markers to genotype 159 isolates of Californian, Mexican, and worldwide origins. Allelic profiles identified 75 multilocus genotypes. A STRUCTURE analysis placed them in three groups characterized by different geographic and host ranges, different genic and genotypic diversity, and different reproductive modes. When relationships among genotypes were visualized on a minimum spanning network (MSN), genotypes belonging to the same STRUCTURE group were contiguous, with rare exceptions. A putatively ancestral group 1 had

Putatively younger groups 2 and 3 had lower genic diversity, were both neighbors to group 1 but formed two distinct peripherical sectors of the MSN, and were equally present in agricultural commodities and natural settings in Mexico and California. A few genotypes, especially in groups 2 and 3, were isolated multiple times in different locations and settings. The presence of identical genotypes from the same hosts in different continents indicated that long-distance human-mediated movement of P. cinnamomi had occurred. The presence of identical genotypes at high frequencies in neighboring wildlands and agricultural settings suggest that specific commodities may have been the source of recent wild infestations caused by novel invasive genotypes.
\end{abstract} high genic diversity, included all A1 mating type isolates and all Papuan isolates in the sample, was rarely isolated from natural settings in California and Mexico, and was positioned at the center of the MSN.
Keywords: California, emergent disease, exotic pathogen, novel strain, oomycetes
Invasive species, including exotic pathogens and pests, are among the most serious threats to local biodiversity and a major cause of species extinction (Lowe et al. 2000). Therefore, there is an increasing need to understand specific introduction pathways for exotic organisms to develop adequate containment and control protocols. The introduction of plant pathogens into natural ecosystems through the trade of ornamental plants or agricultural practices is a long-known issue that has recently re-emerged as an important research topic (Dehnen-Schmutz et al. 2010; Jung et al. 2016; Lowe et al. 2000; Santini et al. 2013). Although movement of ornamental and agricultural plants is recognized as a major way of moving pests and pathogens around the world, the emphasis of international phytosanitary containment has been placed mostly on

†Corresponding author: M. Garbelotto; matteog@berkeley.edu

Funding: This research was possible because of funding provided by the U.S. Forest Service Pacific Southwest Region and by the Gordon and Betty Moore Foundation to Matteo Garbelotto. Maria Serrano was partly supported by the Agrifood Campus of International Excellence (ceiA3) postdoc contract (Spanish Government). Alejandra Almaraz-Sanchez was partly supported by a grant from The National Council of Science and Technology of Mexico (Consejo Nacional de Ciencia y Tecnología [CONACYT]).

María Socorro Serrano and Todd Osmundson contributed equally to this work.

*The $\boldsymbol{e}$-Xtra logo stands for "electronic extra" and indicates that one supplementary figure and three supplementary tables are published online.

The author(s) declare no conflict of interest.

(c) 2019 The American Phytopathological Society plants infected by recently described or exotic pathogenic species. In contrast, the re-emergence, or emergence in natural ecosystems, of pathogens long established in agricultural settings has been mostly and unjustly overlooked (Dehnen-Schmutz et al. 2010; Garbelotto 2008).

One reason for this selective emphasis is that regulatory agencies do not have a system in place to regulate pathogens already known to have a broad distribution. This lack of regulation is problematic because broad and even worldwide distributions do not equate to a ubiquitous presence of these biological threats in natural ecosystems. In particular, individual strains or genotypes of invasive pathogens are usually site-specific; therefore, there is a real risk that multiple introductions will result in the introduction of novel strains still absent in a given region (Garbelotto 2008). There is an urgent need to understand the risks associated with the introduction of new genotypes of the same pathogen/pest: these risks are well understood for diseases affecting humans, but the same is not true for plant pathogens and pests (Desprez-Loustau et al. 2007). Most published cases in this area of research have involved either the insurgence of resistance to chemical control agents or increases in the number of highly susceptible hosts (Dixon et al. 1996).

In this study, we used Phytophthora cinnamomi Rands as a model system to study the worldwide movement of a pathogen through human activities, the pathways of introduction of a pathogen from agricultural into natural settings, and the emergence of new invasive strains. P. cinnamomi is a soilborne Oomycete pathogen associated with a large number of hosts worldwide (Erwin and Ribeiro 1996; Hardham 2005; Zentmyer 1983); it is currently listed as one of the 100 worst invasive organisms in the world (Lowe et al. 2000). First 
isolated in Sumatra (Rands 1922), this heterothallic organism is thought to be indigenous to Papua New Guinea, where maximum genetic diversity is encountered (Linde et al. 1999; Old et al. 1984, 1988). However, its center of origin may include other parts of East and Southern Asia (Arentz 2017; Arentz and Simpson 1986). The current global distribution of this organism appears to be the result of the intercontinental movement of infected soil and plant material associated with the horticultural trade during the past 100 years (Arentz 2017; Jung et al. 2016; Linde et al. 1999; Zentmyer 1988).

In addition to being a significant pathogen of horticultural crops (Erwin and Ribeiro 1996), P. cinnamomi has been identified as a pathogen in natural ecosystems (Brasier 1996; EPPO/CABI 2011; Garbelotto et al. 2006; Hardham 2005; Nagle et al. 2010; Swiecki et al. 2003; Tainter 1997; Tainter et al. 2000). The impact of its presence in natural settings varies depending on the ecosystem and the inherent susceptibility of the plant species involved (Hayden et al. 2013). The impact of $P$. cinnamomi can be dramatic in ecosystems such as the Jarrah forests of Western Australia (Shearer et al. 2004), the white oak forests of Central Mexico (Tainter 1997; Tainter et al.2000), and manzanita populations in the foothills of the Sierra Nevada mountains in California (Swiecki et al. 2003). In other ecosystems such as the oak woodlands in Iberia (Brasier 1996; Gómez-Aparicio et al. 2012; Sánchez et al. 2002), the Eastern United States (Balci et al. 2010; Eggers et al. 2012; McConnell and Balci 2014; Nagle et al. 2010), Southern California (Garbelotto et al. 2006), and pine stands of the Eastern United States (French 1989; Griffin et al. 2009; McKeever and Chastagner 2016), the presence of $P$. cinnamomi is associated with a condition known as oak decline in oaks (Brasier 1996) or littleleaf disease in pines (French 1989). In these cases, $P$. cinnamomi acts like a less aggressive pathogen that is mostly responsible for pruning the fine roots of infected hosts (Brasier 1996; Garbelotto et al. 2006). Although not directly leading to plant mortality, infection of the fine roots significantly reduces the resilience of trees and leads to mortality at the onset of limiting conditions, such as a persistent drought (Eggers et al. 2012; Garbelotto et al. 2006), or results in premature senescence and a short lifespan (French 1989; Griffin et al. 2009). Although mortality in these cases is cyclical and linked to environmental and site conditions (Garbelotto 2008; Griffin et al. 2009; Nagle et al. 2010), the decline of infected trees may occur over large areas, with obvious deleterious ecological and economic effects. A third scenario consists of spatially limited infestations, such as those reported for Kauris in New Zealand (Beever et al. 2009), Pacific madrones in California (Fichtner et al. 2009), and sweet chestnuts in Southern Europe (Vannini and Vettraino 2001; Vettraino et al. 2001). In these cases, mortality of individual trees or of small clusters of trees has been reported; it is not clear whether this more limited effect is intrinsically caused by mixed host composition and diversity in these ecosystems, or if it is because the pathogen was only recently introduced in these ecosystems (Vannini and Vettraino 2001).

The presence of $P$. cinnamomi in three different natural California ecosystems has been reported relatively recently (Garbelotto et al. 2006; Rizzo and Fichtner 2009; Swiecki et al. 2003). Therefore, California may be an ideal region to study to understand the pathways through which a soilborne pathogen of agricultural importance may be released in nature and to confirm the insurgence of new strains, as reported for agricultural commodities (Pagliaccia et al. 2013). The identification of founder individuals responsible for new wildland infestations may be easier in California because in younger infestations, founder effects should still be strong and genetic similarity should be high between those founder individuals that were the source of the outbreak and the invasive individuals currently causing the outbreak (Garbelotto 2008). The California example is also particularly interesting because $P$. cinnamomi, although clearly exotic, is not regulated because of its abundance in agricultural and horticultural settings. One may assume that the sources of invasions of natural ecosystems may be identified in populations already established in nonnatural systems throughout the state. This presumption, although reasonable, needs to be tested by evaluating whether identical pathogen genotypes show evidence of a link between commodities and natural ecosystems.

In this study, we adopted a population genetics approach for a California collection and a worldwide collection of P. cinnamomi from natural ecosystems and from commodities. Second, we performed the same analysis for a Mexican collection of isolates to identify the possible source of some California outbreaks. This second analysis was prompted by the observation that some novel California outbreaks were seemingly concurrent with novel Mexican outbreaks.

Our specific aims were as follows. (i) Use a microsatellite analysis to draw inferences about the broad genetic structure of $P$. cinnamomi at the worldwide level and to determine the host and geographic range of individual genotypes. (ii) Use multilocus genotyping to identify long-distance movement of the pathogen through the movement of infested commodities, cross-contamination among commodities, the specific sources of the release of the pathogen from commercial commodities to natural settings in California and Mexico, and emergent young "invasive" genotypes affecting multiple commodities that are present in different world regions.

\section{MATERIALS AND METHODS}

Isolates. We used a two-tiered sampling approach. Our study of pathways of worldwide movement of $P$. cinnamomi used isolates available in historical collections, with some dating back to 1966 , emphasizing geographic breadth over depth within any given geographic region. Conversely, intensive sampling of California and Mexico populations after 2000 was designed to examine both recent wildland outbreaks and chronic infestation of agricultural commodities to understand the number and sources of introductions of this pathogen in natural settings. Together, these studies allowed us to obtain a satisfactory picture of instances of long-distance global movement of the pathogen and its short movement from commodities to natural settings in California and Mexico.

Table 1 summarizes the host or substrate, the geographic provenance, and the mating type of all isolates used during the first study. In summary, 75 isolates from eight distinct countries were used, including 61 from the United States. A total of 44 isolates were collected from natural or "wild" settings comprising all three major reports of $P$. cinnamomi in the wild in California, namely the oak woodlands in San Diego county $(n=6)$, Manzanita-dominated communities in acidic Oxysol soils of Amador County in the Sierra Nevada foothills $(n=23)$, and the woodlands in the San Francisco Bay Area $(n=15)$. The sample also included 17 isolates from agricultural and nursery commodities located in California $(n=15)$ and Florida $(n=2)$. Worldwide isolates were collected from a natural setting in Taiwan $(n=1)$, Papua New Guinea $(n=4)$, Australia $(n=1)$, and an oak infestation in the state of Colima, Mexico $(n=1)$ (Tainter et al. 2000). Seven additional isolates used in the study were from agricultural commodities in China (4), South Africa (2), and Madagascar (1). Table 2 lists all Mexican isolates used for the second analysis, including 64 isolates from five different states: Colima (7), Jalisco (7), Guerrero (6), Estado de Mexico (7), and Michoacán (37), with 27 from natural settings and 37 from agricultural commodities. A total of 12 isolates from the first analysis were reanalyzed together with Mexican isolates, allowing us to compare the two analyses. The 12 isolates used in both analyses included six pairs of closely related genotypes, with each pair being genetically distant from the others. The reasons for performing two distinct analyses are detailed here.

DNA extraction and simple sequence repeat (SSR) amplification. Culture collections were maintained on $1.7 \%$ corn meal agar, subcultured on selective pimaricin-ampicillin-rifampicinpentachloronitrobenzene agar (Erwin and Ribeiro 1996), incubated at room temperature in the dark for 3 weeks, and transferred to $12 \%$ pea broth (120 $\mathrm{g}$ of peas/liter) liquid medium (Eyre and Garbelotto 
2015) at room temperature for 7 days. Mycelia were harvested by filtering the broth through Whatman paper and lyophilizing the filtrites for $24 \mathrm{~h}$. DNA was extracted from $20 \mathrm{mg}$ of lyophilized mycelium using the Gentra Puregene Tissue DNA kit (Qiagen) and eluted in $50 \mu \mathrm{l}$ ultrapure water as described by Ivors et al. (2006).

Four di-nucleotide SSR (simple sequence repeat or microsatellite) loci described by Dobrowolski et al. $(1998,2002)$ were amplified: d39, e16, g10, and g13. Two primer pairs-g13(1) and $\mathrm{g} 13(4)$ - are needed to genotype this locus, likely because of a mutation in $\mathrm{g} 13$ priming site for some isolates. The d39 and g13 loci exhibit genetic linkage (Dobrowolski et al. 2002). The amplification reactions were performed in a final volume of $10 \mu \mathrm{l}$ using $10 \mathrm{ng}$ of genomic DNA, $200 \mu \mathrm{M}$ of dNTPs, $1.5 \mathrm{mM}$ of $\mathrm{MgCl}_{2}, 0.1 \mu \mathrm{M}$ of each primer, and 1 unit of Taq polymerase. All loci except g13(4) were amplified using the following PCR conditions: initial denaturation of $2 \mathrm{~min}$ at $96^{\circ} \mathrm{C} ; 6$ cycles of denaturation at $96^{\circ} \mathrm{C}$ for $30 \mathrm{~s}$; annealing at $66^{\circ} \mathrm{C}$ for $30 \mathrm{~s}$; and extension at $72^{\circ} \mathrm{C}$ for $30 \mathrm{~s}$. Next, 20 cycles of denaturation for $30 \mathrm{~s}$ at $96^{\circ} \mathrm{C}$, annealing for $30 \mathrm{~s}$ at $60^{\circ} \mathrm{C}$, and extension for $30 \mathrm{~s}$ at $72^{\circ} \mathrm{C}$ were performed The microsatellite g13(4) was amplified using an initial denaturation for $2 \mathrm{~min}$ at $96^{\circ} \mathrm{C}$; 6 cycles of denaturation for $30 \mathrm{~s}$ at $96^{\circ} \mathrm{C}$; annealing for $30 \mathrm{~s}$ at $64^{\circ} \mathrm{C}$; and extension for $30 \mathrm{~s}$ at $72^{\circ} \mathrm{C}$. Next, 20 cycles of denaturation for $30 \mathrm{~s}$ at $96^{\circ} \mathrm{C}$, annealing for $30 \mathrm{~s}$ at $58^{\circ} \mathrm{C}$, and extension for $30 \mathrm{~s}$ at $72^{\circ} \mathrm{C}$ were performed. The forward primer was labeled with 6-FAM, and size determination of the PCR products was conducted on an ABI377 sequencer (Applied Biosystems) using GeneScan 500 LIZ (Thermo Fisher Scientific) as the size marker. Amplifications were conducted in 96-well plates in a MiQ single-color real-time PCR Detection System thermal cycler (Bio-Rad); negative and positive controls (isolates of known genotype) were included in each plate. For the Mexican analysis, amplifications were conducted 3 years later in a CFX96 thermal cycler (Bio-Rad), and fragments were sized on an ABI3730 DNA Analyzer using GeneScan 500 LIZ as the size marker. For statistical analysis, the allele fragment length was substituted with the number of repeats corresponding to the allele size.

Genetic and statistical analyses. Cumulative allelic profiles were used to identify multilocus genotypes (MG), each characterized by a unique combination of alleles, using the $\mathrm{R}$ package poppr version 2.5.0 (Kamvar et al. 2014). To ensure that sampling was sufficiently saturated in the worldwide/California set of isolates, given the resolution of the genetic markers used, we constructed a genotype accumulation curve as described by Grünwald et al. (2017).

The statistical confidence of identifying unique individuals with the selected microsatellite loci was assessed by calculating the probability of identity, $P_{(\mathrm{ID})}$. However, $P$. cinnamomi has three characteristics that may violate the Hardy-Weinberg equilibrium and linkage equilibrium assumptions of $P_{(\mathrm{ID})}$ calculation: occurrence of clonality; possible population substructure; and linkage between two of the loci used in this study (d39 and g13). To address these issues, we performed complete clone correction of each dataset (worldwide/ California and Mexico), included a more conservative $P_{(\mathrm{ID})}$ measure, and calculated the $P_{(\mathrm{ID})}$ values with and without one of the two linked loci. Therefore, we calculated four values of $P_{(\mathrm{ID})}$ for each dataset for all four loci versus one locus removed using two formulas: the more conservative measure for siblings described by Waits et al. (2001) was as follows:

$$
P_{(\mathrm{IDsib})}=0.25+\left(0.5 \Sigma p_{i}^{2}\right)+\left[0.5\left(\Sigma p_{i}^{2}\right)^{2}\right]-\left(0.25 \Sigma p_{i}^{4}\right)
$$

where $p_{i}$ is the frequency of the $i$ th allele. We also performed the following commonly used measure of Paetkau and Strobeck (1994):

$$
P_{(\mathrm{ID})}=\Sigma p_{i}^{4}+\Sigma \Sigma\left(2 p_{i} p_{j}\right)^{2}
$$

where $p_{i}$ and $p_{j}$ are two allele frequencies, $p_{i} \neq p_{j}$.
For each dataset, the two $P_{(\mathrm{ID})}$ measures were calculated for each locus; the multilocus genotype was calculated as the product of the individual per-locus genotype probabilities. For calculations removing one of the linked loci, the locus with the lower heterozygosity ( $\mathrm{d} 39$ for both datasets) was removed. Allele frequencies were calculated for each clone-corrected dataset using the round robin method of Parks and Werth (1993) as implemented in poppr 2.5.0.

Relationships among individual multilocus genotypes were visualized by calculating the matrix of pairwise genetic distances using the software Genodive (Meirmans and Van Tienderen 2004) and the repeat number-based metric of Bruvo et al. (2004). The distance matrix was used to generate a minimum spanning network (MSN) using poppr 2.8.1 (Kamvar et al. 2014) to visualize the relatedness among the multilocus genotypes. One MSN tree was generated for the worldwide/California set of isolates, and one was generated for the Mexican set of isolates. The analysis of the Mexican isolates also included 12 $P$. cinnamomi isolates representing the different clusters obtained by the first SSR analysis and regenotyped for consistency with the protocols and technology used in the latter analysis to avoid batch effects.

An inference of population genetic structure was conducted using STRUCTURE software (Pritchard et al. 2000) with genome admixing allowed and with linkage assumed between SSRs g13(1) and g13(4) (Dobrowolski et al. 2002). Both the worldwide/ California and the Mexican datasets were clone-corrected by eliminating any identical genotypes that were isolated from the same site to eliminate any obvious bias in the sampling intensity across sites. In the analysis, we maintained identical genotypes from distant locations because we believe this clonal component is key to understanding the broader genetic structure and pathways of spread of this plant pathogen.

All STRUCTURE runs used a burn-in of 1,000,000 iterations and a sample of 5,000,000 iterations, and they were automated using StrAuto version 1.0 (Chhatre and Emerson 2017). The optimal value of $\mathrm{K}$ (number of populations) was determined from 10 replicate runs of $\mathrm{K}$ values from 1 to 8 using STRUCTURE HARVESTER (Earl and von Holdt 2011) to implement the $\Delta K$ method of Evanno et al. (2005). STRUCTURE output files were merged in CLUMPP v.1.1.2 (Jakobsson and Rosenberg 2007) and graphed using DISTRUCT v. 1.1 (Rosenberg 2004).

To infer the most likely mode of reproduction of different $P$. cinnamomi populations, we calculated the index of association $\mathrm{I}_{\mathrm{A}}$ and the standardized index of association $\mathrm{r}_{\mathrm{bar}} \mathrm{D}$ using poppr v.2.8.1 independently for each STRUCTURE group in both datasets. For the worldwide/California analysis, calculations were performed for the two groups identified by the $K=2$ scenario and for the three groups identified by the $\mathrm{K}=3$ scenario; this was performed for a total of four groups because one group perfectly overlapped during the two analyses. Calculations were performed on fully clone-corrected sets, for which only a single representative per genotype was left in the analysis. Hypothesis tests of linkage equilibrium were conducted using the one-sided permutation test implemented in poppr v.2.8.1.

The following diversity indices were also calculated as described by Mascheretti et al. (2009) using the R package poppr version 2.5.0 (Kamvar et al. 2014): eMLG = the number of expected MLGs based on rarefaction with a minimum sample size of 10 individuals (Hurlbert 1971); H = Shannon-Wiener index of MLG diversity (Shannon 2001); Stoddart and Taylor's index, $\mathrm{G}=1 / \Sigma p_{i}^{2}$ (Stoddart and Taylor 1988), where $p_{i}$ is the frequency of the $i$ th MG; lambda $=$ Simpson's index (Simpson 1949); $\mathrm{E}_{5}=$ genotypic evenness (Grünwald et al. 2003); and $\mathrm{H}_{\exp }=$ genic diversity (expected heterozygosity) (Nei 1978). Calculations were performed for the STRUCTURE groups of the aforementioned isolates for the $I_{A}$ analysis, which were subjected to partial clone correction during which identical genotypes from distant locations were retained in 
the dataset; however, identical genotypes from the same site were excluded to avoid sampling bias.

\section{RESULTS}

Worldwide variability in and genetic diversity of P. cinnamomic. All four SSRs were highly polymorphic, and two were trisomic (i.e., included three alleles for some genotypes). Cumulatively, 44 alleles differentiated 23 MGs in the worldwide/ California analysis (Tables 1 and 3). Thirteen MGs were singletons represented by a single isolate, but the most common MGs were MG18 $(n=24)$ and MG08 $(n=15)$. Several isolates belonging to the same MG were found at a great distance, often on different continents, on the same or different hosts (Table 1). The genotype accumulation curve indicated that sampling was close to saturation (Fig. 1); therefore, it was adequate to answer our research questions. The probability of identity values ranged from $2.46 \times 10^{-3}\left(P_{(\mathrm{ID}) \mathrm{sib}}\right.$ for three loci) to $5.62 \times 10^{-5}\left(P_{(\mathrm{ID})}\right.$ for four loci) for the worldwide/ California dataset, and from $5.15 \times 10^{-3}\left(P_{(\mathrm{ID}) \text { sib }}\right.$ for three loci) to $5.62 \times 10^{-5}\left(P_{(I D)}\right.$ for four loci) for the Mexico dataset (Supplementary Table S1). Therefore, it can be assumed with reasonable confidence that these microsatellite loci are capable of distinguishing individuals.

The optimal value of $\mathrm{K}=2$ was determined using the $\Delta K$ method for the worldwide/California samples (Supplementary Fig. S1); however, we used $\mathrm{K}=3$ for the final analysis to show additional potential substructures (Fig. 2A). The presence of three distinct groups was confirmed by the Mexican analysis, which, by including a broad representation of genotypes belonging to the group identified here as group worldwide 2 (WW2; represented by a single genotype and, thus, weakly supported in the worldwide analysis), clearly identified this group as statistically significant and distinct from the other groups. Each of the three STRUCTURE groups consisted of genotypes that were also contiguous in the MSN, with the exception of a single sample (P-6493 from Rhododendron spp. in China); because of its inconsistent location on the MSN, this sample was excluded from the discussion (Fig. 3). STRUCTURE group worldwide 1 (WW1) included four isolates belonging to mating type $\mathrm{A} 2$ from two locations in California $(n=3$; MG 10) and one location in China ( $n=1 ;$ MG11), and all 16 A1 isolates from the Southern Hemisphere, China, and California. Group WW1 was centrally located in the MSN, with group WW2 emerging from one side and group worldwide 3 (WW3) emerging from the other. All A1 isolates were contiguous in the MSN, with the isolates from Papua New Guinea forming a distinct subgroup of contiguous genotypes within the A1 cluster. Isolates in group WW2 belonged to a single genotype with mating type A2, derived directly from a PNG genotype in group WW1; this group was isolated from wild and commodity hosts in California and Mexico. Group WW1 isolates with the A2 mating type were located at another edge of group WW1 in the MSN; these isolates were found in China and California, and they appeared to be more closely related to an A1

TABLE 1. Information regarding the 75 isolates used in the California and worldwide study

\begin{tabular}{|c|c|c|c|c|c|c|c|c|}
\hline Isolate (alternate code) & Collector, date ${ }^{a}$ & Host & Origin & $\begin{array}{l}\text { U.S.A. county or } \\
\text { Mexican state }\end{array}$ & Mating type & $\mathrm{W} / \mathrm{C}^{\mathrm{b}}$ & $\mathrm{MG}^{\mathrm{c}}$ & STRUCTURE group \\
\hline $\mathrm{mc03}$ & MG, 2001 & Quercus agrifolia & CA, U.S.A. & San Diego & A2 & W & MG01 & WW3 \\
\hline $\mathrm{mc07}$ & MG, 2001 & Quercus sp. & CA, U.S.A. & San Diego & $\mathrm{A} 2$ & $\mathrm{~W}$ & MG01 & WW3 \\
\hline $\operatorname{mc} 21(3 a 2)$ & TS, 2003 & Arctostaphylos myrtifolia & CA, U.S.A. & Amador & $\mathrm{A} 2$ & W & MG02 & WW3 \\
\hline $\mathrm{mc} 12$ & MG, 2003 & Abies nordmanniana & CA, U.S.A. & El Dorado & $\mathrm{A} 2$ & $\mathrm{C}$ & MG03 & Admixed \\
\hline $\operatorname{mc} 16$ & MG, 2003 & Abies sp. & CA, U.S.A. & - & A2 & $\mathrm{C}$ & MG04 & WW3 \\
\hline $\operatorname{mc} 19(1 b 2)$ & TS, 2003 & A. myrtifolia & CA, U.S.A. & Amador & $\mathrm{A} 2$ & $\mathrm{~W}$ & MG04 & WW3 \\
\hline mc29 (7b1) & TS, 2003 & A. myrtifolia & CA, U.S.A. & Amador & A 2 & W & MG04 & WW3 \\
\hline $\operatorname{mc} 31(150)$ & TS, 2003 & A. myrtifolia & CA, U.S.A. & Amador & A2 & W & MG04 & WW3 \\
\hline $\operatorname{mc} 35(20 \mathrm{a} 1)$ & TS, 2003 & A. myrtifolia & CA, U.S.A. & Amador & A2 & W & MG04 & WW3 \\
\hline $\operatorname{mc} 17$ & MG, 2003 & Soil $^{\mathrm{d}}$ & CA, U.S.A. & Alameda & A2 & W & MG05 & WW3 \\
\hline P-2183 (PNG 8062) & DS, 1972 & Soil & $\mathrm{PNG}^{\mathrm{e}}$ & & A1 & W & MG06 & WW1 \\
\hline P-3658 (CSIRO A121) & FA, 1988 & Castanopsis sp. & PNG & & A1 & W & MG07 & WW1 \\
\hline $\mathrm{mc04}$ & FT, 2000 & Quercus sp. & Mexico & Colima & $\mathrm{A} 2$ & W & MG08 & WW2 \\
\hline mc09 & MG, 2003 & Arctostaphylos sp. & CA, U.S.A. & Amador & A2 & W & MG08 & WW2 \\
\hline $\operatorname{mc} 14$ & MG, 2003 & Pseudotsuga menziesii & CA, U.S.A. & El Dorado & A2 & $\mathrm{C}$ & MG08 & WW2 \\
\hline $\operatorname{mc} 15$ & MG, 2003 & Abies spp. & CA, U.S.A. & El Dorado & A 2 & $\mathrm{C}$ & MG08 & WW2 \\
\hline $\operatorname{mc} 18(1 \mathrm{c} 0)$ & TS, 2003 & A. myrtifolia & CA, U.S.A. & Amador & A2 & W & MG08 & WW2 \\
\hline $\operatorname{mc} 20(2 \mathrm{a} 1)$ & TS, 2003 & A. myrtifolia & CA, U.S.A. & Amador & A2 & W & MG08 & WW2 \\
\hline $\operatorname{mc} 23(5 b 1)$ & TS, 2003 & A. myrtifolia & CA, U.S.A. & Amador & A2 & W & MG08 & WW2 \\
\hline mc24 (10a2) & TS, 2003 & Arctostaphylos viscida & CA, U.S.A. & Amador & $\mathrm{A} 2$ & W & MG08 & WW2 \\
\hline $\operatorname{mc} 25(11 b 2)$ & TS, 2003 & A. myrtifolia & CA, U.S.A. & Amador & A2 & W & MG08 & WW2 \\
\hline $\operatorname{mc} 26(12 \mathrm{a} 2)$ & TS, 2003 & A. myrtifolia & CA, U.S.A. & Amador & $\mathrm{A} 2$ & $\mathrm{~W}$ & MG08 & WW2 \\
\hline $\operatorname{mc} 27(13 a 2)$ & TS, 2003 & A. myrtifolia & CA, U.S.A. & Amador & A2 & W & MG08 & WW2 \\
\hline $\operatorname{mc} 30(9 \mathrm{a} 1)$ & TS, 2003 & A. viscida & CA, U.S.A. & Amador & A2 & W & MG08 & WW2 \\
\hline $\operatorname{mc} 34(19 a 5)$ & TS, 2003 & A. myrtifolia & CA, U.S.A. & Amador & A 2 & W & MG08 & WW2 \\
\hline $\operatorname{mc} 37(24$ 1) & TS, 2003 & A. myrtifolia & CA, U.S.A. & Amador & A2 & W & MG08 & WW2 \\
\hline $\operatorname{mc} 39(2625)$ & TS, 2003 & A. myrtifolia & CA, U.S.A. & Amador & A2 & W & MG08 & WW2 \\
\hline P-3656 (CSIRO A118) & FA, 1988 & Nothofagus sp. & PNG & & A1 & W & MG09 & WW1 \\
\hline $\operatorname{mc} 33(17 \mathrm{a} 1)$ & TS, 2003 & A. viscida & CA, U.S.A. & Amador & $\mathrm{A} 2$ & W & MG10 & WW1 \\
\hline $\operatorname{mc} 38(252)$ & TS, 2003 & A. myrtifolia & CA, U.S.A. & Amador & A2 & W & MG10 & WW1 \\
\hline P-2301 (ATCC 46686) & GAZ, 1976 & Rhododendron sp. & CA, U.S.A. & & $\mathrm{A} 2$ & $\mathrm{C}$ & MG10 & WW1 \\
\hline P-3232 & PT, 1986 & Rhododendron sp. & China & & A2 & $\mathrm{C}$ & MG11 & WW1 \\
\hline P-3233 & PT, 1986 & Camellia japonica & China & & A1 & $\mathrm{C}$ & MG12 & WW1 \\
\hline P-2096 (ATCC 46667) & WT, 1968 & C. japonica & CA, U.S.A. & & A1 & $\mathrm{C}$ & MG13 & WW1 \\
\hline
\end{tabular}

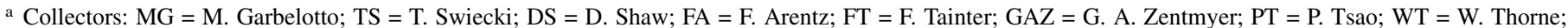
$\mathrm{LM}=\mathrm{L}$. Marais; $\mathrm{SC}=\mathrm{S}$. Campbell; $\mathrm{TD}=\mathrm{T}$. Dolan; RP = R. Ploetz; JR = J. Reid; MJ = M. Jackson; PJA = P.-J. Ann; JB = J. Brun; HB = H. Brodrick. n/a = unknown.

${ }^{\mathrm{b}}$ Collected in the wild (W) or from an agricultural commodity (C).

c Multilocus genotype determined by allele frequencies in Table 3 .

d Soil collected near symptomatic California (CA) bay laurels (Umbellularia californica) or symptomatic Pacific madrones (Arbutus meziesii).

e PNG = Papua New Guinea. 
genotype isolated from Camellia japonica in China. STRUCTURE group WW3 appeared to emerge from one A2 MG belonging to group WW1. Group WW3 included multiple MGs, both from wild and commodity hosts, but all were isolated in the United States. The presence of multiple isolates from distant locations and various hosts but belonging to the same MG was more evident in STRUCTURE groups WW2 and WW3, whereas group 1 included mostly singletons.

Genotypic analysis revealed examples of long-distance movement, cross-commodity spread, and pathogen release in wild settings. An examination of genotypes comprising multiple isolates uncovered a number of likely links between geographic areas, commodities, and agricultural and wild settings. STRUCTURE group WW1 contained 12 genotypes and was defined as the "old world group" because it included all Papuan isolates, which were presumed to be from within the native range of the pathogen. This group contained four different genotypes from Papua New Guinea wildlands and five genotypes isolated from seven agricultural or plantation forestry hosts in China, Australia, South Africa, and Madagascar (avocado, pineapple, grapes, camellia or rhododendron, and eucalyptus). The observed genetic and geographic patterns provided strongly suggested the occurrence of long-distance human-mediated movement of $P$. cinnamomi both within and between commodities (Table 1). Withincommodity long-distance movement was evidenced by the identical genotype MG13 found on Chinese and Californian
Camellia. Between-commodity movement was indicated by an identical genotype found on California avocado and Taiwanese pineapple (MG20), by genotype MG22 found on South African grapes and Australian eucalyptus, and by genotype MG20 being necessarily derived from genotype MG13, with the latter isolated from Chinese and California Camellia (Fig. 3). Transmission from commodities to wild habitats was also suggested by our results: genotype MG10, found on Chinese and Californian Rhododendron, was found on wild manzanitas in the foothills of the Sierra Nevada mountains in California, thus identifying ornamental rhododendrons as one of the likely sources for this wild infestation.

STRUCTURE group 2 (both WW2 in the worldwide/California analysis and MEX2 in the Mexican analysis) appeared to be derived directly from a PNG genotype in group WW1 (Fig. 3), and it was "contained" between genotypes belonging to the STRUCTURE group MEX1 in the Mexican analysis (Fig. 4), meaning that genotypes at both ends of the group 2 cluster were related to MEX1 genotypes. During the worldwide/California analysis, this group was the only one to comprise a single MG (Fig. 3, Table 1), and it contained broad geographic and host distributions. This group/MG provides evidence of long-distance movement between California and Central Mexico after having been isolated from a severe disease outbreak on oaks in the Mexican state of Colima and on Christmas trees in both countries (true firs and Douglas firs; see results of the Mexican analysis) and on two wild manzanita species (Arctostaphylos viscida and the endangered A. myrtifolia) in California.

TABLE 1. (Continued from previous page)

\begin{tabular}{|c|c|c|c|c|c|c|c|c|}
\hline Isolate (alternate code) & Collector, date ${ }^{a}$ & Host & Origin & $\begin{array}{l}\text { U.S.A. county or } \\
\text { Mexican state }\end{array}$ & Mating type & $\mathrm{W} / \mathrm{C}^{\mathrm{b}}$ & $\mathrm{MG}^{\mathrm{c}}$ & STRUCTURE group \\
\hline P-2100 (ATCC 46668) & GAZ, 1969 & C. japonica & CA, U.S.A. & & A1 & $\mathrm{C}$ & MG13 & WW1 \\
\hline P-2170 & GAZ, 1972 & C. japonica & CA, U.S.A. & & A1 & $\mathrm{C}$ & MG13 & WW1 \\
\hline P-3237 & PT, 1986 & C. japonica & China & & A1 & $\mathrm{C}$ & MG13 & WW1 \\
\hline P-6493 (Shen B14) & PT, 1989 & Rhododendron sp. & China & & - & $\mathrm{C}$ & MG14 & WW1 \\
\hline $\mathrm{mc06}$ & LM, 2001 & Persea americana & CA, U.S.A. & San Diego & A2 & $\mathrm{C}$ & MG15 & WW3 \\
\hline $\mathrm{mc08}$ & MG, 2001 & Q. agrifolia & CA, U.S.A. & San Diego & A2 & $\mathrm{W}$ & MG16 & WW3 \\
\hline $\operatorname{mc} 10$ & MG, 2001 & Q. agrifolia & CA, U.S.A. & San Diego & A2 & W & MG16 & WW3 \\
\hline mc22 (4b2) & TS, 2003 & A. myrtifolia & CA, U.S.A. & Amador & A2 & W & MG17 & WW3 \\
\hline $\operatorname{mc} 32(160)$ & TS, 2003 & A. myrtifolia & CA, U.S.A. & Amador & A2 & $\mathrm{W}$ & MG17 & WW3 \\
\hline A4 & TS, 2005 & Arbutus menziesii & CA, U.S.A. & San Mateo & A2 & W & MG18 & WW3 \\
\hline D2-2 & TS, 2005 & A. menziesii & CA, U.S.A. & San Mateo & A2 & $\mathrm{W}$ & MG18 & WW3 \\
\hline D8-3A & TS, 2005 & A. menziesii & CA, U.S.A. & San Mateo & A2 & $\mathrm{W}$ & MG18 & WW3 \\
\hline D904 & TS, 2005 & A. menziesii & CA, U.S.A. & San Mateo & A2 & $\mathrm{W}$ & MG18 & WW3 \\
\hline $\mathrm{mc01}$ & MG, 2001 & Quercus agrifolia & CA, U.S.A. & San Diego & A2 & $\mathrm{W}$ & MG18 & WW3 \\
\hline $\mathrm{mc0} 2$ & MG, 2001 & Q. agrifolia & CA, U.S.A. & San Diego & A2 & $\mathrm{W}$ & MG18 & WW3 \\
\hline $\mathrm{mc05}$ & $\mathrm{n} / \mathrm{a}$ & Vaccinium corymbosum & FL, U.S.A. & & A2 & $\mathrm{C}$ & MG18 & WW3 \\
\hline $\mathrm{mc} 11$ & MG, 2003 & Abies concolor & CA, U.S.A. & El Dorado & $\mathrm{A} 2$ & $\mathrm{C}$ & MG18 & WW3 \\
\hline mc28 (6b1) & TS, 2003 & A. myrtifolia & CA, U.S.A. & Amador & A2 & $\mathrm{W}$ & MG18 & WW3 \\
\hline $\operatorname{mc} 36(22 \mathrm{a} 2)$ & TS, 2003 & A. myrtifolia & CA, U.S.A. & Amador & A2 & W & MG18 & WW3 \\
\hline P-2288 (ATCC 46685) & GAZ, 1975 & Pinus radiata & CA, U.S.A. & Santa Cruz & A2 & $\mathrm{C}$ & MG18 & WW3 \\
\hline P-2428 & $\mathrm{SC}, 1985$ & P. americana & CA, U.S.A. & & A2 & $\mathrm{C}$ & MG18 & WW3 \\
\hline P-2444 & TD, 1985 & P. americana & CA, U.S.A. & & A2 & $\mathrm{C}$ & MG18 & WW3 \\
\hline $\operatorname{mc} 40(29 a 2)$ & TS, 2003 & A. viscida & CA, U.S.A. & Amador & A2 & $\mathrm{W}$ & MG18 & WW3 \\
\hline P-543 & TS, 2005 & Soil & CA, U.S.A. & Santa Cruz & A2 & $\mathrm{W}$ & MG18 & WW3 \\
\hline P-544 & TS, 2005 & Soil & CA, U.S.A. & San Rafael & A2 & $\mathrm{W}$ & MG18 & WW3 \\
\hline P-545 & TS, 2005 & Soil & CA, U.S.A. & San Rafael & $\mathrm{A} 2$ & W & MG18 & WW3 \\
\hline P-546 & TS, 2005 & Soil & CA, U.S.A. & Sonoma & A2 & W & MG18 & WW3 \\
\hline P-547 & TS, 2005 & Soil & CA, U.S.A. & Sonoma & A2 & W & MG18 & WW3 \\
\hline P-549 & TS, 2005 & Soil & CA, U.S.A. & Sonoma & A2 & W & MG18 & WW3 \\
\hline P-6490 (Collier 26) & RP, 1989 & P. americana & FL, U.S.A. & & A2 & $\mathrm{C}$ & MG18 & WW3 \\
\hline $\mathrm{PC} 004$ & TS, 2005 & A. menziesii & CA, U.S.A. & Marin & A2 & $\mathrm{W}$ & MG18 & WW3 \\
\hline P-541 & TS, 2005 & A. menziesii & CA, U.S.A. & Santa Cruz & A2 & $\mathrm{W}$ & MG18 & WW3 \\
\hline P-542 & TS, 2005 & Soil & CA, U.S.A. & Santa Cruz & A2 & $\mathrm{W}$ & MG18 & WW3 \\
\hline P-3662 (CSIRO A126) & FA, 1988 & Castanopsis sp. & PNG & & A1 & $\mathrm{W}$ & MG19 & WW1 \\
\hline P-2138 (ATCC 38581) & JR/MJ, 1970 & P. americana & CA, U.S.A. & & A1 & $\mathrm{C}$ & MG20 & WW1 \\
\hline P-6379 (Pcip1-2) & PJA, 1989 & Ananas comosus & Taiwan & & A1 & W & MG20 & WW1 \\
\hline P-2121 (ATCC 46672) & JB, 1966 & P. americana & Madagascar & & A1 & $\mathrm{C}$ & MG21 & WW1 \\
\hline P-2159 (ATCC 46678) & HB, 1971 & Vitis vinifera & South Africa & & A1 & $\mathrm{C}$ & MG22 & WW1 \\
\hline P-2160 (ATCC 46679) & $\mathrm{HB}, 1971$ & $V$. vinifera & South Africa & & A1 & $\mathrm{C}$ & MG22 & WW1 \\
\hline P-3664 (CSIRO A138) & $\mathrm{n} / \mathrm{a}$ & Eucalyptus sp. & Australia & & A1 & W & MG22 & WW1 \\
\hline P-2021 (ATCC46660) & GAZ, 1966 & C. japonica & CA, U.S.A. & & A1 & $\mathrm{C}$ & MG23 & WW1 \\
\hline
\end{tabular}


Infested Christmas tree farms and manzanita woodlands were both located in the Sierra Nevada foothills; this geographic proximity suggested a link between wild and agricultural outbreaks. The discovery that this genotype was associated with a large outbreak on oaks in Colima, Mexico (Tainter et al. 2000), and the recent manzanita outbreak in California discussed here, prompted us to investigate whether isolates belonging to group 2 may have arrived in California from Mexico. To answer this question, we performed a second genetic analysis of a large collection of P. cinnamomi isolates from Mexico.

Group WW3 appeared to be closely related to new world A2 genotypes belonging to group WW1 rather than to the Papuan genotypes that represent the presumed native range of $P$. cinnamomi (Arentz 2017; Arentz and Simpson 1986; Old et al. 1984). This group included eight genotypes (Fig. 3, Table 1); because all isolates were from North America, we referred to WW3 as the North American group. Three isolates belonging to genotypes MG04 and MG18 came from the California Christmas tree industry: two from two different true fir species and one from Monterey pine. Genotype MG04 was isolated both from a true fir species in a Christmas tree farm in the Sierra Nevada foothills (California) and from wild manzanitas growing in the same foothills, thus indicating a possible agricultural source for this wild infestation. Multiple group WW3 isolates belonging to genotypes MG15 and MG18 were found in avocado orchards, indicating a close link to this industry. The discovery of MG18 in avocado orchards in California and Florida suggested a role for this industry in the long-distance movement of P. cinnamomi. MG18 was also isolated 24 times from a variety of wildland hosts, including oaks in Southern California, manzanitas in the Sierra Nevada foothills, and Pacific madrones in the greater San Francisco Bay Area, as well as in additional agricultural contexts, including blueberries from Florida, white fir Christmas trees in the Sierra Nevada foothills, and Monterey pine Christmas trees in the San Francisco Bay Area. The presence of this same genotype on multiple hosts and locations suggested it was an aggressive, invasive clonal genotype. Its presence on Christmas trees and wild manzanitas in the Sierra Nevada foothills of California, on avocados and wild oaks in San Diego County (California), and, finally, on Christmas trees and wild Pacific madrones in the San Francisco Bay Area was indicative of the potential movement of this pathogen from specific agricultural settings to natural habitats, facilitating expansion in the host range.

Analysis of Mexican isolates showed the occurrence of unique genotypes, links to worldwide and California isolates, and evidence for interhost transmission. Mexican samples were processed 3 years after the processing of worldwide/ California samples and using different batches of reagents and different equipment. Results from the 12 reference isolates processed during both analyses indicated that allelic profiles were similar between analyses, but not identical. This was in contrast to the results of the first worldwide/California analysis, in which all samples were processed twice with identical outcomes. Hence, we

TABLE 2. The 64 Mexican isolates and 12 worldwide reference isolates included in the second study ${ }^{\mathrm{a}}$

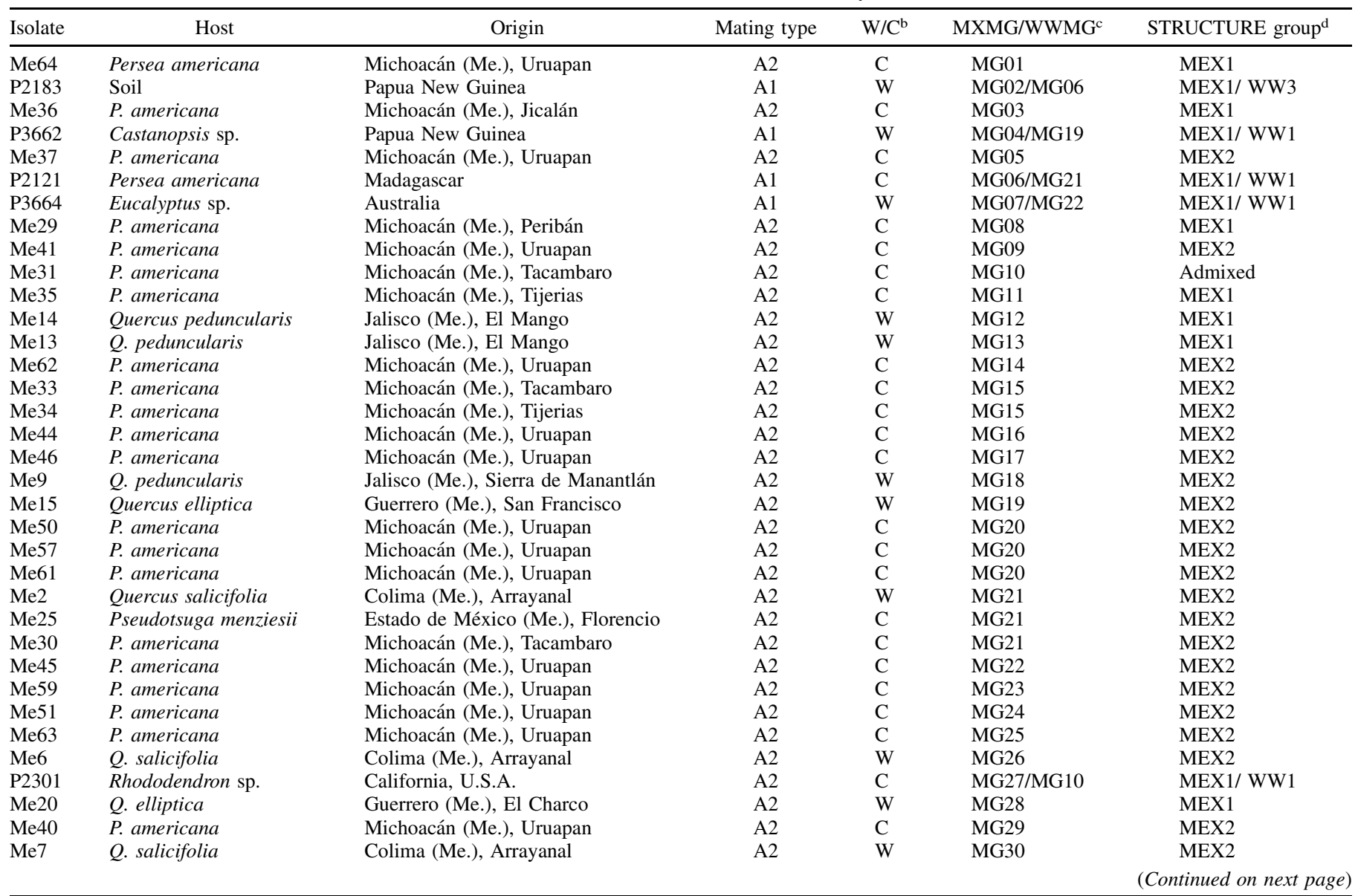

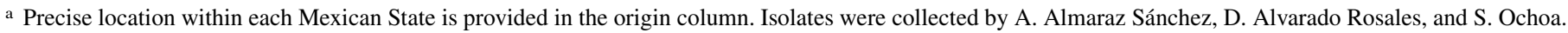
$\mathrm{CA}=$ California; Me. $=$ Mexico.

b $\mathrm{W}=$ wild host $\mathrm{C}=$ host grown as a commodity.

c Multilocus genotype in the Mexican analysis/multilocus genotype in the worldwide analysis based on alleles in Table 5 .

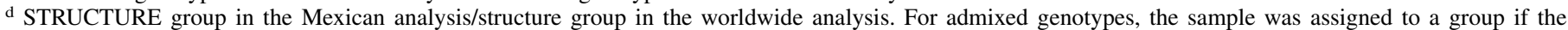
genome corresponded mostly to that group. Isolates with equal or nearly equal admixture proportions between STRUCTURE groups are denoted as admixed. 
opted to perform all analyses for both sets separately using the positioning of the 12 reference isolates to draw comparisons between the two analyses (Tables 2 and 4).

Based on a total of 41 different alleles, 64 Mexican isolates and the 12 reference isolates from the worldwide/California analysis were assigned to $52 \mathrm{MGs}$ (Tables 2 and 4). The optimal $\mathrm{K}$ value for the Mexico analysis was determined as $\mathrm{K}=2$ using the $\Delta K$ method. A $\mathrm{K}=3$ analysis of the Mexican samples resulted in all individuals appearing as admixed, suggesting an overestimation of the true number of populations; therefore, the optimal value of $\mathrm{K}=2$ was used here instead of the $K=3$ value used for the worldwide analysis. The STRUCTURE analysis of these isolates identified two groups (Fig. 2B); the Mexican group MEX1 included 11 Mexican genotypes, all consisting of singletons (i.e., one isolate per genotype), as well as all reference A1 and Papuan isolates belonging to the worldwide/California STRUCTURE group WW1, two California A2 isolates belonging to STRUCTURE group WW3, and the only two A2 isolates from California belonging to STRUCTURE group WW1. However, when the STRUCTURE group assignment was overlaid on the Mexican MSN (Fig. 4), it became apparent that STRUCTURE group MEX1 included three subgroups: 1a, 1b, and 1c. These subgroups were not contiguous on the MSN, and they matched well with worldwide/California STRUCTURE groups WW1 (MEX1b and 1c) and WW3 (MEX1a). Subgroup MEX1a included seven genotypes: the two genotypes connecting Mexican subgroup 1a with the rest of the network were from avocados cultivated in Michoacán, whereas the remaining five genotypes came from wild oaks in the Mexican state of Jalisco. Subgroup MEX1b included a single isolate with mating type A2 from a wild oak in the state of Guerrero; this isolate appeared to be a close relative of MG06 from avocado in Madagascar and MG07 from eucalyptus in Australia, with both carrying mating type A1 and belonging to the worldwide/ California STRUCTURE group WW1. Subgroup MEX1c included Papuan A1 isolates and Californian A2 isolates belonging to STRUCTURE group WW1. The majority of Mexican isolates belonged to STRUCTURE group MEX2, matched the worldwide/ California STRUCTURE group WW2, and included 28 different genotypes. Six genotypes included multiple isolates; for four of these genotypes, isolates came from different locations, suggesting these were clonal invasive genotypes that have been spread by humans. Mexican MG38 perfectly matched California MG08. These genotypes were both isolated from multiple hosts, some wild and some cultivated; however, one host-Douglas fir on Christmas tree farms-was common to both, providing evidence of a likely international pathway of movement for this pathogen.

A comparison of population genetic indices between STRUCTURE groups WW3 (mostly including isolates from California) and MEX1a and between WW2 (again with isolates exclusively from California) and MEX2 showed two inverse trends (Table 5). California's WW2 had minimal genotypic diversity (one genotype)

TABLE 2. (Continued from previous page)

\begin{tabular}{|c|c|c|c|c|c|c|}
\hline Isolate & Host & Origin & Mating type & $\mathrm{W} / \mathrm{C}^{\mathrm{b}}$ & MXMG/WWMG ${ }^{\mathrm{c}}$ & STRUCTURE group $^{d}$ \\
\hline Me53 & P. americana & Michoacán (Me.), Uruapan & A2 & $\mathrm{C}$ & MG31 & MEX2 \\
\hline $\mathrm{Mc08}$ & Quercus agrifolia & San Diego Co., California, U.S.A. & $\mathrm{A} 2$ & $\mathrm{~W}$ & MG32/MG16 & MEX1/ WW3 \\
\hline Me10 & Q. peduncularis & Jalisco (Me.), Sierra de Manantlán & $\mathrm{A} 2$ & $\mathrm{~W}$ & MG33 & MEX2 \\
\hline Me16 & Q. elliptica & $\begin{array}{l}\text { Guerrero (Me.), San Francisco } \\
\text { (CA, U.S.A.) }\end{array}$ & A2 & $\mathrm{W}$ & MG34 & MEX2 \\
\hline Me60 & P. americana & Michoacán (Me.), Uruapan & A2 & $\mathrm{C}$ & MG35 & MEX2 \\
\hline $\mathrm{Me} 47$ & P. americana & Michoacán (Me.), Uruapan & $\mathrm{A} 2$ & $\mathrm{C}$ & MG36 & MEX2 \\
\hline $\mathrm{Me} 48$ & P. americana & Michoacán (Me.), Uruapan & $\mathrm{A} 2$ & $\mathrm{C}$ & MG36 & MEX2 \\
\hline Me58 & P. americana & Michoacán (Me.), Uruapan & $\mathrm{A} 2$ & $\mathrm{C}$ & MG36 & MEX2 \\
\hline $\operatorname{Mc} 20$ & Arctostaphylos myrtifolia & Amador Co., California, U.S.A. & A2 & $\mathrm{W}$ & MG37/MG08 & MEX2/ WW2 \\
\hline Mc39 & A. myrtifolia & Amador Co., California, U.S.A. & $\mathrm{A} 2$ & $\mathrm{~W}$ & MG38/MG08 & MEX2/ WW2 \\
\hline Me19 & Q. elliptica & Guerrero (Me.), Magueyitos & $\mathrm{A} 2$ & $\mathrm{~W}$ & MG38 & MEX2 \\
\hline $\operatorname{Me} 22$ & P. menziesii & Estado de México (Me.), Mesa Rica & $\mathrm{A} 2$ & $\mathrm{C}$ & MG38 & MEX2 \\
\hline $\operatorname{Me} 27$ & P. menziesii & Estado de México (Me.), Florencio & $\mathrm{A} 2$ & $\mathrm{C}$ & MG38 & MEX2 \\
\hline $\mathrm{Me} 3$ & Q. salicifolia & Colima (Me.), Arrayanal & A2 & $\mathrm{W}$ & MG38 & MEX2 \\
\hline Me4 & Q. salicifolia & Colima (Me.), Arrayanal & A2 & $\mathrm{W}$ & MG38 & MEX2 \\
\hline $\mathrm{Me} 42$ & P. americana & Michoacán (Me.), Uruapan & A2 & $\mathrm{C}$ & MG38 & MEX2 \\
\hline Me5 & Q. salicifolia & Colima (Me.), Arrayanal & $\mathrm{A} 2$ & $\mathrm{~W}$ & MG38 & MEX2 \\
\hline Me17 & Q. elliptica & Guerrero (Me.), Xalpatláhuac & A2 & $\mathrm{W}$ & MG39 & MEX2 \\
\hline Me18 & Q. elliptica & Guerrero (Me.), Xalpatláhuac & $\mathrm{A} 2$ & $\mathrm{~W}$ & MG39 & MEX2 \\
\hline $\operatorname{Me} 21$ & P. menziesii & Estado de México (Me.), Mesa Rica & $\mathrm{A} 2$ & $\mathrm{C}$ & MG39 & MEX2 \\
\hline $\mathrm{Me} 24$ & P. menziesii & Estado de México (Me.), Mesa Rica & $\mathrm{A} 2$ & $\mathrm{C}$ & MG39 & MEX2 \\
\hline $\operatorname{Me} 28$ & P. americana & Michoacán (Me.), Cerritos & $\mathrm{A} 2$ & $\mathrm{C}$ & MG39 & MEX2 \\
\hline Me49 & P. americana & Michoacán (Me.), Uruapan & $\mathrm{A} 2$ & $\mathrm{C}$ & MG39 & MEX2 \\
\hline Me52 & P. americana & Michoacán (Me.), Uruapan & A2 & $\mathrm{C}$ & MG39 & MEX2 \\
\hline Me55 & P. americana & Michoacán (Me.), Uruapan & A2 & $\mathrm{C}$ & MG39 & MEX2 \\
\hline Me54 & P. americana & Michoacán (Me.), Uruapan & $\mathrm{A} 2$ & $\mathrm{C}$ & MG40 & MEX2 \\
\hline Me38 & P. americana & Michoacán (Me.), Uruapan & A2 & $\mathrm{C}$ & MG41 & MEX2 \\
\hline Me12 & $Q$. peduncularis & Jalisco (Me.), Sierra de Manantlán & $\mathrm{A} 2$ & $\mathrm{~W}$ & MG42 & MEX1 \\
\hline Me8 & Q. peduncularis & Jalisco (Me.), Sierra de Manantlán & A2 & $\mathrm{W}$ & MG43 & MEX1 \\
\hline Mc16 & Abies sp. & California, U.S.A. & $\mathrm{A} 2$ & $\mathrm{C}$ & MG44/MG04 & MEX1/ WW3 \\
\hline $\mathrm{Me} 43$ & P. americana & Michoacán (Me.), Uruapan & $\mathrm{A} 2$ & $\mathrm{C}$ & MG45 & MEX2 \\
\hline Me56 & P. americana & Michoacán (Me.), Uruapan & A2 & $\mathrm{C}$ & MG46 & MEX1 \\
\hline $\operatorname{Me} 23$ & P. menziesii & Estado de México (Me.), Mesa Rica & A2 & $\mathrm{C}$ & MG47 & MEX2 \\
\hline $\operatorname{Me} 26$ & P. menziesii & Estado de México (Me.), Florencio & A2 & $\mathrm{C}$ & MG47 & MEX2 \\
\hline Me39 & P. americana & Michoacán (Me.), Uruapan & $\mathrm{A} 2$ & $\mathrm{C}$ & MG47 & MEX2 \\
\hline Me1 & Q. salicifolia & Colima (Mexico), Arrayanal & A2 & $\mathrm{W}$ & MG48 & MEX2 \\
\hline $\mathrm{Me} 32$ & P. americana & Michoacán (Me.), Ario de rosales & A2 & $\mathrm{C}$ & MG49 & MEX1 \\
\hline Me11 & $Q$. peduncularis & Jalisco (Me.), Sierra de Manantlán & A2 & $\mathrm{W}$ & MG50 & MEX1 \\
\hline P2100 & Camellia japonica & California, U.S.A. & A1 & $\mathrm{C}$ & MG51/MG13 & MEX1/ WW1 \\
\hline P3237 & C. japonica & China & A1 & $\mathrm{C}$ & MG51/MG13 & MEX1/ WW1 \\
\hline Mc38 & A. myrtifolia & Amador Co., California, U.S.A. & $\mathrm{A} 2$ & $\mathrm{~W}$ & MG52/MG10 & MEX1/ WW1 \\
\hline
\end{tabular}


TABLE 3. The 23 multilocus genotypes (MGs) expressed as the number of repeats produced by the four simple sequence repeats for the California and worldwide isolates

\begin{tabular}{|c|c|c|c|c|c|c|}
\hline MG & Origin/hosts ${ }^{\mathrm{a}}$ & $n(\Sigma=75)$ & $\mathrm{d} 39(\Sigma$ alleles $=11)$ & e16 $(\Sigma$ alleles $=6)$ & g10 $(\Sigma$ alleles $=9)$ & $\mathrm{g} 13(\Sigma$ alleles $=18)$ \\
\hline MG01 & U.S.A. (CA) & 2 & $19 / 19$ & $14 / 15$ & $10 / 29$ & $16 / 25 / 28$ \\
\hline MG02 & U.S.A. (CA) & 1 & $17 / 17$ & $14 / 15$ & $10 / 30$ & $16 / 25 / 28$ \\
\hline MG03 & U.S.A. (CA) & 1 & $17 / 17$ & $14 / 15$ & $10 / 29$ & $12 / 18 / 28$ \\
\hline MG05 & U.S.A. (CA) & 1 & $17 / 17$ & $14 / 15$ & $10 / 31$ & $16 / 25 / 28$ \\
\hline MG06 & Papua New Guinea & 1 & $14 / 20$ & $10 / 14$ & 9/10/11 & $14 / 22$ \\
\hline MG07 & Papua New Guinea & 1 & $13 / 13$ & $10 / 14$ & 9/10/11 & $14 / 23 / 28$ \\
\hline MG08 & U.S.A. (14, CA), Mexico (1) & 15 & $12 / 34$ & $11 / 11$ & $8 / 9$ & $12 / 18 / 28$ \\
\hline MG11 & China & 1 & $12 / 12$ & $14 / 14$ & $10 / 31$ & $13 / 16 / 27$ \\
\hline MG12 & China & 1 & $12 / 12$ & $14 / 14$ & $8 / 10$ & 23/null \\
\hline MG13 & U.S.A. (3, CA), China (1) & 4 & $12 / 12$ & $14 / 14$ & $8 / 10$ & $23 / 31$ \\
\hline MG14 & China & 1 & $15 / 15$ & $14 / 14$ & $5 / 12$ & $15 / 15$ \\
\hline MG15 & U.S.A. (CA) & 1 & $11 / 17$ & $13 / 15$ & $10 / 29$ & $16 / 25 / 28$ \\
\hline MG16 & U.S.A. (CA) & 2 & $11 / 17$ & $12 / 13$ & $10 / 29$ & $16 / 25 / 28$ \\
\hline MG17 & U.S.A. (CA) & 2 & $11 / 17$ & $14 / 15$ & $10 / 30$ & $16 / 25 / 28$ \\
\hline MG22 & Australia (1), South Africa (2) & 3 & $9 / 11$ & $14 / 14$ & $9 / 10$ & $21 / 51$ \\
\hline MG23 & U.S.A. (CA) & 1 & $9 / 11$ & $14 / 14$ & $8 / 10$ & $23 / 31$ \\
\hline
\end{tabular}

a $\mathrm{CA}=$ California; FL = Florida.

\section{Genotype accumulation curve for worldwide_strata}

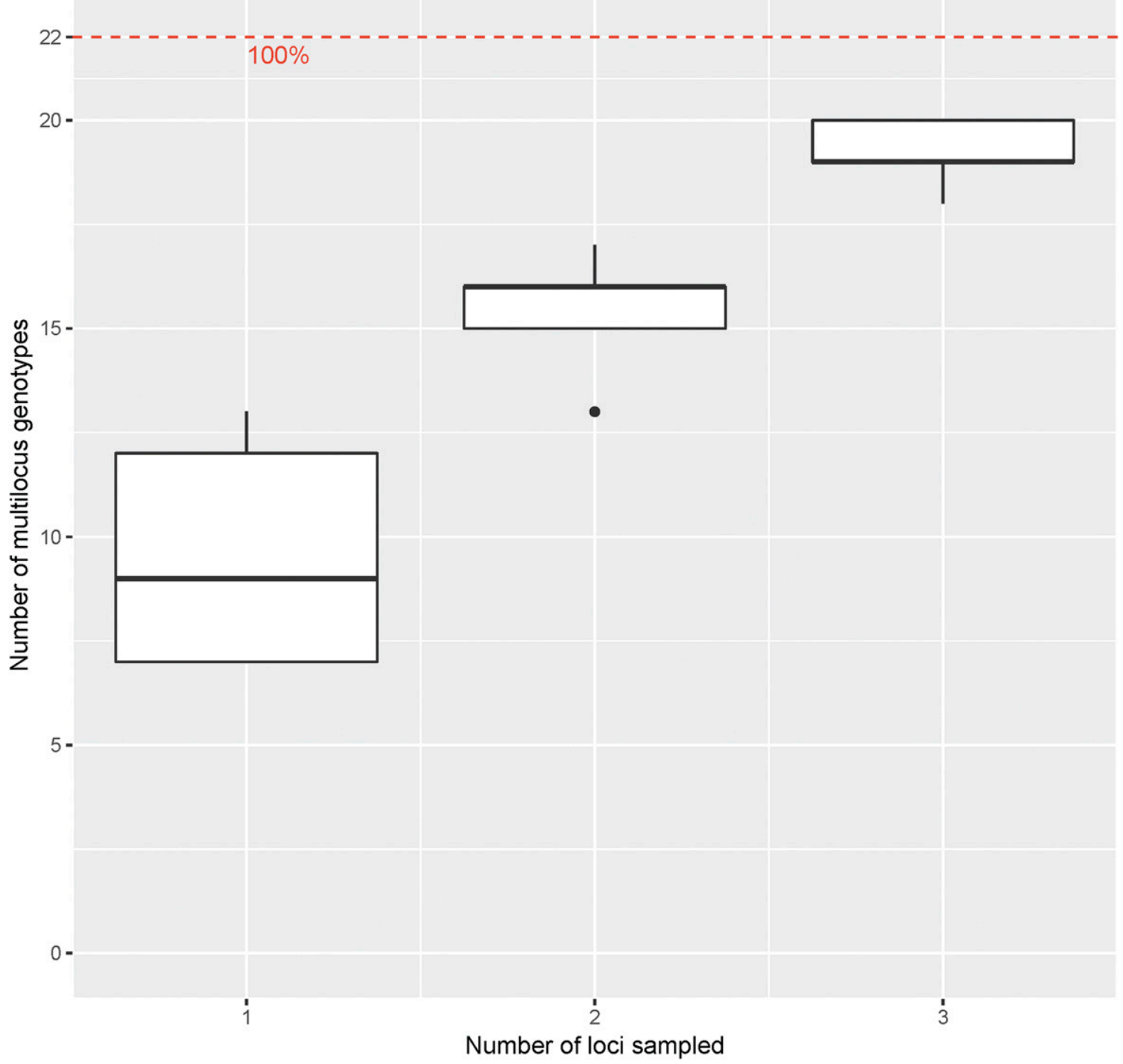

Fig. 1. Genotype accumulation curve for the worldwide/California study. 
and low genic diversity, whereas MEX2 has extremely high genotypic diversity and higher genic diversity, suggesting Mexico may be a primary or secondary center of origin for this group that may have arrived in California only recently. In contrast, group WW3 showed higher genic diversity in California than in Mexico; therefore, its presence may be older in California. The comparable level of genotypic diversity observed between the two populations may be caused by the fact that evenness is reduced in California because of the presence of clonally reproducing genotypes present in different locations.

Several Mexican genotypes (MG21, MG38, MG39) were present in agricultural commodities (e.g., avocados or Douglas firs grown as Christmas trees) and in natural habitats (e.g., oaks). The same was true for the following two pairs of genotypes, with one MG
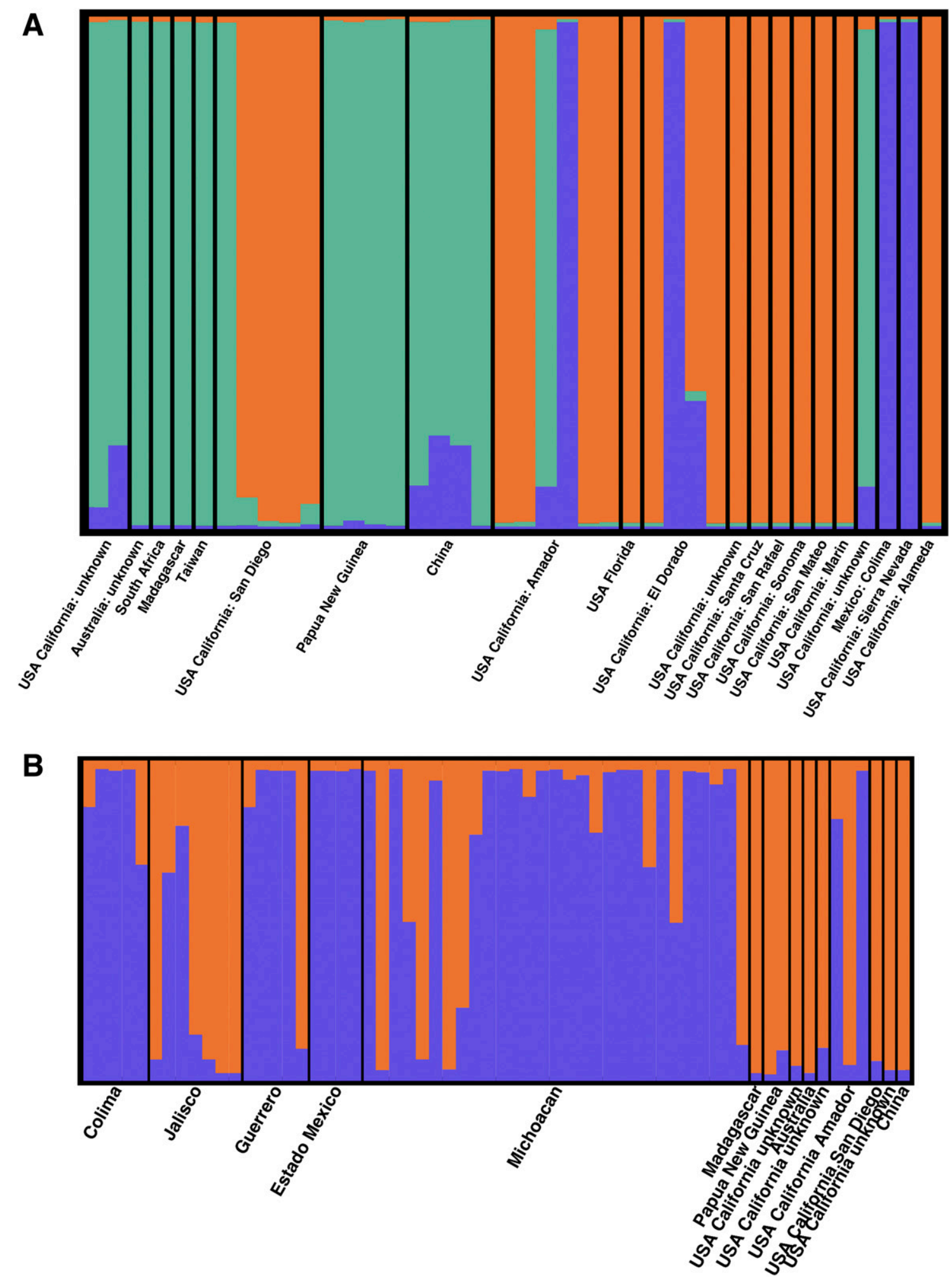

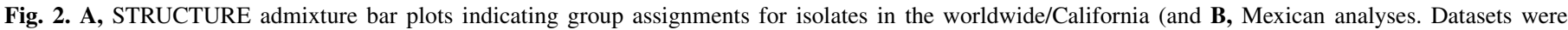

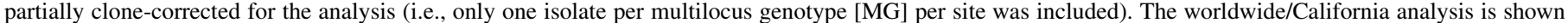
for $\mathrm{K}=3$; when using $\mathrm{K}=2$, isolates in groups 1 and 2 merged into the same group. The Mexican analysis is shown for $\mathrm{K}=2$. 
necessarily deriving from the other in each of the two pairs, based on their location on the MSN: MG26 (oak)-MG23 (avocado) and MG48 (oak)-MG22 (avocado) (Fig. 4, Table 2). No Mexican study site included both wild and cultivated hosts; therefore, it was not possible to provide direct evidence in favor of contagion between the two types of hosts.

$P$. cinnamomi outbreaks in California wild populations exhibit links to agricultural commodities. In addition to the wildland outbreaks sampled as part of the Mexican study described, our sampling scheme included intensive sampling from three wildland outbreaks in California: oak woodland mortality in San Diego County, manzanita dieback in the Sierra Nevada foothills, and Pacific madrone mortality in the greater San Francisco Bay Area. Each of these three cases showed clear genetic links to an agricultural outbreak located in close proximity. The outbreak on wild oaks in San Diego County was associated with three genotypes (MG01, MG16, and MG18), all from STRUCTURE group WW3. MG18 was found on avocados and oaks growing in the same general area. Additionally, the MSN showed oak genotype MG16 from San Diego County to be a terminal genotype (i.e., at the outer edge of the MSN) necessarily derived from MG15 from avocado, also in San Diego County (Fig. 3). The outbreak on manzanitas in the Sierra Nevada foothills (Amador and Eldorado Counties) was associated with at least six genotypes: MG10 from STRUCTURE group WW1, MG08 from group WW2, and MG02, MG04, MG17, and MG18 from group WW3. MG10 has been previously isolated from an ornamental Rhododendron; MG08 has been previously isolated from a true fir and from a Douglas fir on a Christmas tree farm in Eldorado County; and MG04 and MG18 have also been previously isolated from true firs on a Christmas tree farm in Eldorado County. The outbreak on wild Pacific madrones in the San Francisco Bay Area

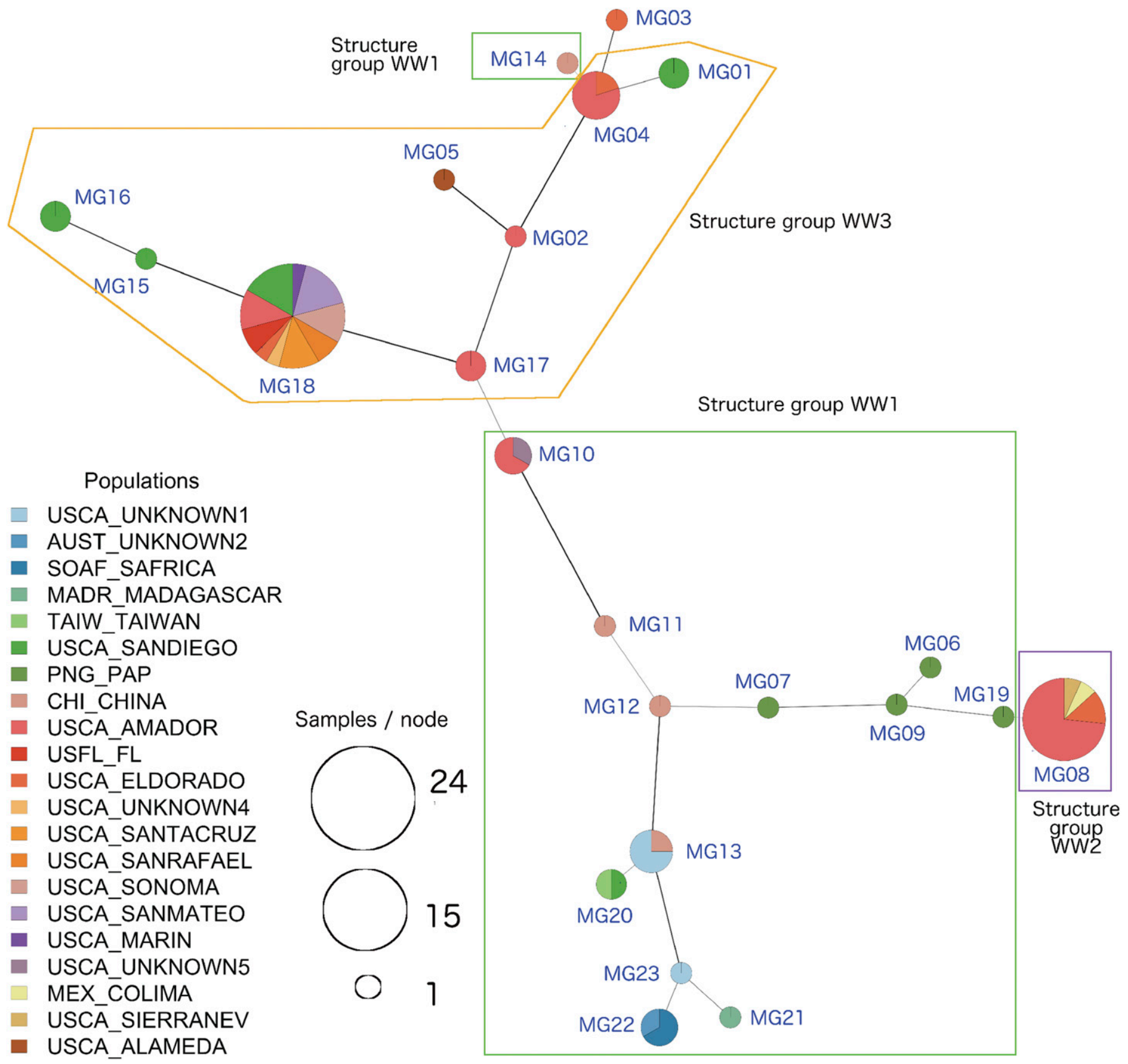

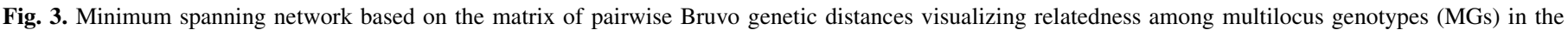
worldwide/California analysis. 
(California) was associated with the single genotype MG18 belonging to group WW3, which, by including multiple isolates from different hosts and sites, appeared to be an emerging invasive strain linked to the avocado and Christmas tree industries in the same region.

$P$. cinnamomi strains differ in reproductive modes. Linkage disequilibrium, as indicated by significant values of the index of association $\mathrm{I}_{\mathrm{A}}$ (Agapow and Burt 2001; Brown et al. 1980; Smith et al. 1993) $(P<0.0001)$, was characteristic of STRUCTURE group WW1 in the worldwide/California datasets (Table 5). It is noteworthy that this cluster was predominantly characterized by mating type A1 genotypes. STRUCTURE group WW3 and STRUCTURE group MEX2, exclusively characterized by the A2 mating type, showed no linkage disequilibrium in the clonecorrected sets, which was suggestive of sexual reproduction. In both analyses, several genotypes had admixed haplotypes (Fig. 2). These results cumulatively suggested that sexual reproduction, although rare, may not be common when mating type A1 is predominant, but it may occur when mating type A2 occurs.

Comparisons of population genetic indices among STRUCTURE groups suggested three broad categories (Table 5): high genotypic diversity, high genotypic evenness (i.e., reduced presence of clonal genotypes), and high gene diversity not necessarily paired with sexual reproduction but possibly associated with older and larger populations, as occurred in STRUCTURE groups WW1 and MEX1; reduced genotypic and genic diversity, low genotypic evenness with a significant presence of clonally identical genotypes in distant locations, possibly sexually reproducing but younger in age, as occurred in STRUCTURE group WW3; and high genotypic diversity, low genic diversity, intermediate genotypic evenness with some clonally reproducing genotypes but with possible sexual reproduction, young, and experiencing large population growth, as shown in STRUCTURE group MEX2. We did not include WW2 in this summary because it was represented by a single genotype.

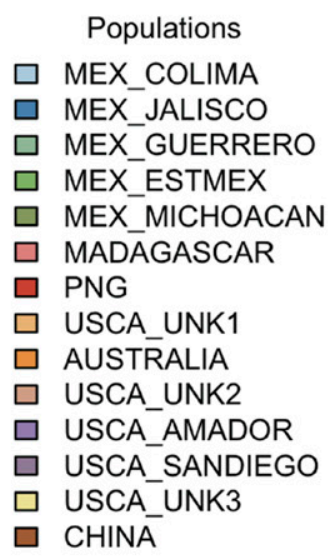

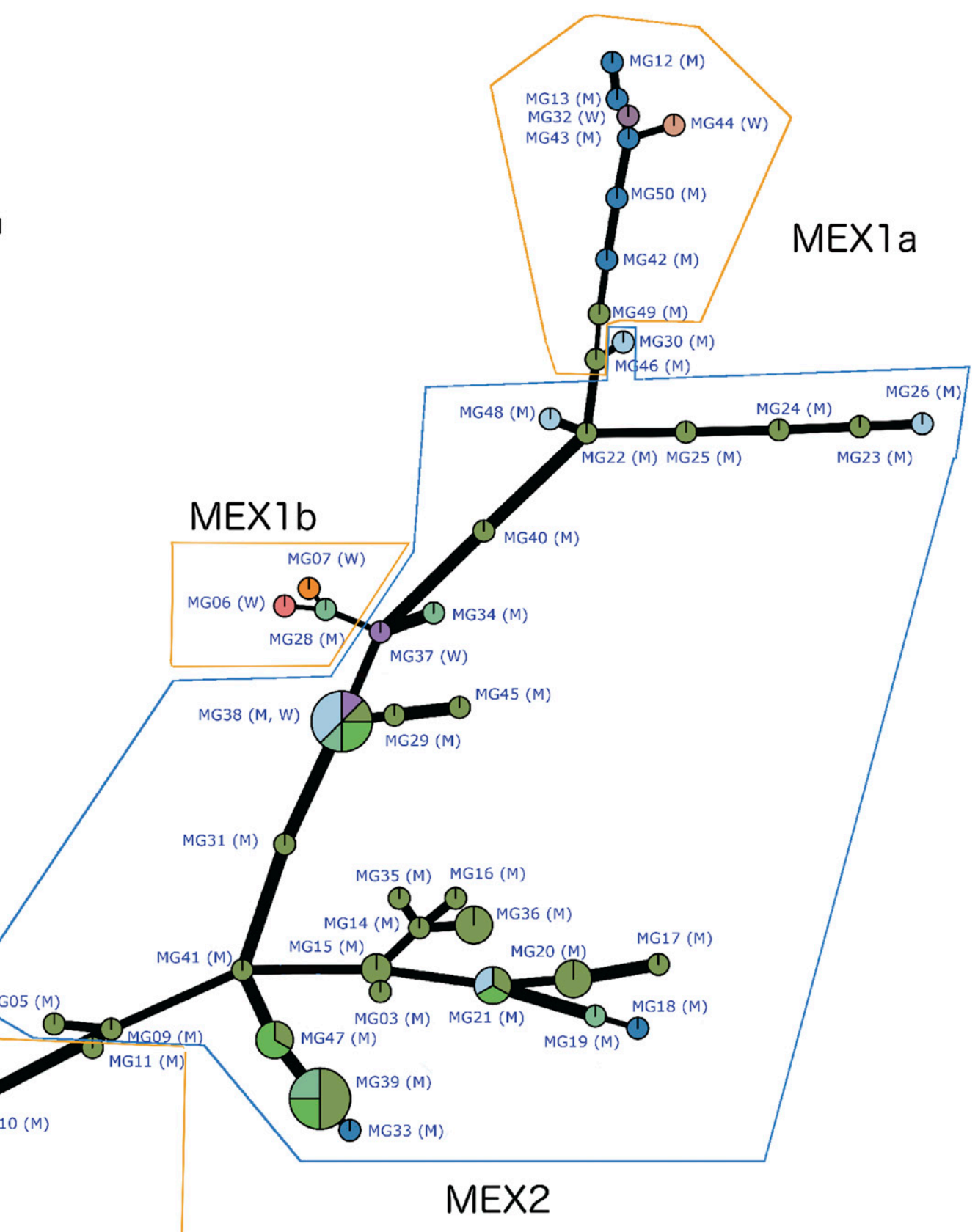

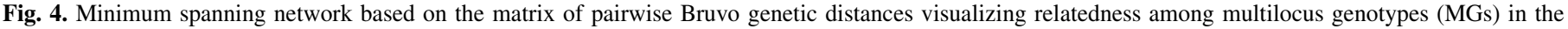
Mexican analysis. 


\section{DISCUSSION}

Human activities play a pivotal role in the introduction of exotic organisms both in novel regions and in previously uninfested natural ecosystems (Croucher et al. 2013; Dehnen-Schmutz et al. 2010; Garbelotto 2008; Garbelotto et al. 2018; Garbelotto and Pautasso 2012; Jung et al. 2016; Wingfield et al. 2001), and specific introduction histories can be reconstructed using the powerful tools provided by population genetics and genetic epidemiological studies (Croucher et al. 2013; Garbelotto 2008; Garbelotto and Gonthier 2013; Mascheretti et al. 2008; Wingfield et al. 2001). Accurate knowledge of pathways of spread of plant pathogens is pivotal to prevent further introductions.
Like several other Phytophthora species, $P$. cinnamomi is a pathogen of global concern (Hayden et al. 2013; Jung et al. 2016), and it has recently been reported as the cause of significant and novel disease outbreaks, both in natural ecosystems and in a variety of cultivated commodities (Hardham 2005; Jung et al. 2016; Jung et al. 2017; Quynh et al. 2017; Rizzo and Fichtner 2009). Genetic epidemiological studies in this organism are facilitated by the knowledge of the putative native range of the pathogen (Arentz 2017; Arentz and Simpson 1986; Old et al. 1984) and by the existence of genetic markers previously developed for local population studies (Dobrowolski et al. 1998, 2002, 2003; Linde et al. 1997, 1999; Pagliaccia et al. 2013). The present study extended this previous knowledge by examining links within and

TABLE 4. The 52 multilocus genotypes (MGs) expressed as the number of repeats produced by the four simple sequence repeats for the Mexican isolates and international reference specimens

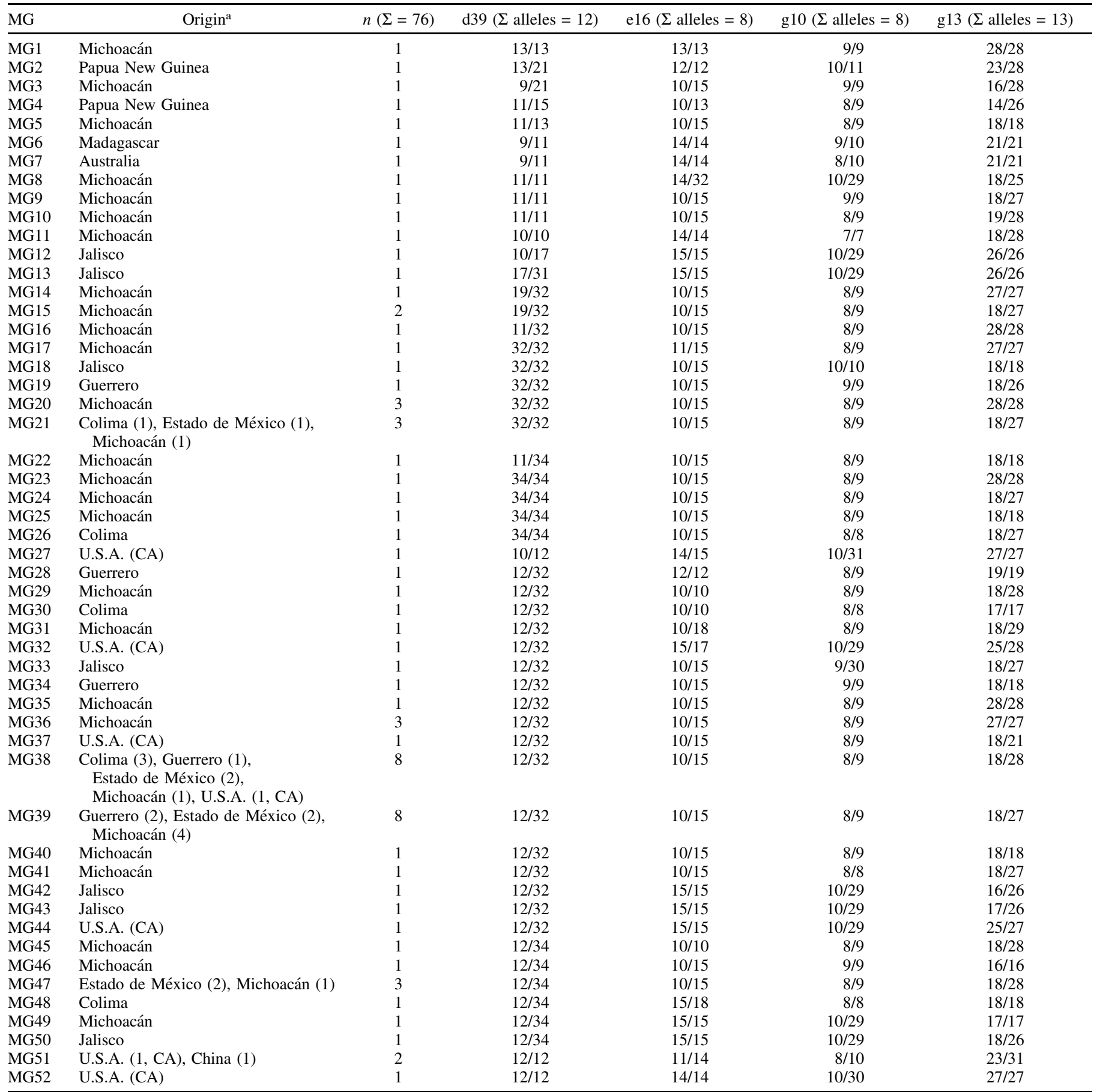

${ }^{\mathrm{a}} \mathrm{CA}=$ California. 
between agricultural and forest disease outbreaks on a global scale and in detail for two regions of North America. The present study is valuable because it genotyped recent intensively collected samples from natural ecosystems and agricultural settings in California and Mexico together with historical collections (some dating back to 1966), incorporated wildlands and agricultural settings from a wide geographic range, and included areas such as Papua New Guinea and Taiwan, which are presumed to be within the native range of P. cinnamomi.

Although the use of four SSR markers provided somewhat limited discrimination potential, we provided evidence that the probability of a given multilocus genotype occurring by chance alone based on underlying allele frequencies of the four SSR markers used in this study was sufficiently low. Our calculations did not take into account rapid convergence events associated with loss of heterozygosity, gene duplication or trisomy, and other genetic events, which have been reported to occur in Phytophthora species (Dobrowolski et al. 2002; Kasuga et al. 2016). However, the conclusions of this study were based on multiple examples provided by isolates obtained during different times and from different world regions, thus enhancing the robustness of these conclusions. Finally, given the discriminating power of the SSRs used, we showed that our sampling was scaled adequately and that genotypic diversity was saturated. We should also clarify that, differently from other authors who based their conclusions on the presence and distribution of clonal lineages (Dobrowolski et al. 2003), we based all of our inferences almost exclusively on the presence of identical genotypes in different sites and on different commodities. Occasionally, inferences were made in the presence of two genotypes that are closest relatives and positioned in such a way on the edges of the MSNs that the distal one at the very end of a branch in the MSN has to be derived from the other.

Origin and spread of $\boldsymbol{P}$. cinnamomi through agriculture. Because it was the only group including isolates from the putative native range of the pathogen, including both A1 and A2 mating types, displaying the highest level of genic diversity and positioned in the center of the worldwide/California MSN, group WW1 was strongly supported as ancestral within the context of the sample analyzed in this study. It is interesting to note that all Papuan A1 isolates were contiguous in the MSN, and that all A1 isolates were also contiguous. This distribution pattern supported the hypothesis that $P$. cinnamomi ancestrally was characterized by A1 mating type populations that evolved in a broad region stretching from Papua New Guinea to East Asia, as suggested by Arentz (2017). The appearance of the A2 mating type (whether by mating type switch or by a different unknown mechanism) may have occurred later and at least twice independently, because A2 genotypes are positioned in two distinct portions of the MSN at two different edges of STRUCTURE group WW1. Sexual reproduction seemed to be present only in groups generated after the emergence of the A2 mating type. Group WW1 genotypes from wild populations within the putative native range of the pathogen were closely related to genotypes isolated from many widespread agricultural commodities, highlighting the likely role of agriculture in the initial diffusion of this pathogen from its native range to a global scale (Hayden et al. 2013). The presence of identical genotypes within a commodity, even in distant regions of the world, provides further evidence of long-distance dispersal through the plant trade; additionally, the presence of identical genotypes between commodities indicates that pathogen transfer between commodities has also occurred.

Agriculture as a source of $P$. cinnamomi spread to Californian and Mexican wildlands. Several lines of evidence suggest that disease outbreaks in California and Mexico forests originated from agricultural sources. First, most genotypes present in the wild were also detected in agricultural commodities. In the case of wildland infestations in California, we identified the same genotype in commodities and in the wild, and both were identified in the same geographical region, providing even stronger support for a commodity source of wildland infestations. Reports regarding agricultural settings always preceded reports of the wild, which is a strong indication that pathogen movement occurred from agricultural into wild settings, and not vice versa. This order of events is further supported by the observation that California wildland outbreaks are rarely associated with the presence of genotypes from the presumed ancestral STRUCTURE group WW1, but they are predominantly associated with genotypes in the more derived groups WW2 and WW3.

Genotype specificity of invasions: evidence of multiple introductions and implications for disease management. The genetic patterns shown in this study-particularly the association of specific pathogen genotypes with specific hosts and locations-suggest that individual specific $P$. cinnamomi genotypes are historically shared within and sometimes among commodities, and that individual wildland outbreaks have different histories and are caused by different strains of the pathogen. For example, although commodities such as grapes, ornamental plants, and avocados are associated with group WW1 genotypes, the Christmas tree industry in California is not, suggesting that the infection may have been acquired later. This was in agreement with the fact that outbreaks of P. cinnamomi at California Christmas tree farms were first reported as recently as the early 2000s (McKeever and Chastagner 2016).

The presence of identical genotypes isolated multiple times from different hosts and distant locations (e.g., MG08 and MG18 in the worldwide/California analysis) suggested the recent emergence of particularly invasive microbial genotypes in groups WW2 and WW3 that are currently being actively spread both within commodities and from commodities into the wild. Because not all genotypes are everywhere, and because these novel emergent genotypes appear to be particularly invasive, it is important to

TABLE 5. Diversity indices for worldwide (WW)/California and Mexican (MEX) STRUCTURE groups ${ }^{\mathrm{a}}$

\begin{tabular}{|c|c|c|c|c|c|c|c|c|c|c|c|}
\hline Population & $\mathrm{N}^{\mathrm{b}}$ & MLG $^{c}$ & eMLG & SE & $\mathrm{H}$ & $\mathrm{G}$ & lambda & E.5 & Hexp & $\mathrm{Ia}^{* \mathrm{~d}}$ & $\operatorname{rbarD} *$ \\
\hline $\mathrm{WW} 1, \mathrm{k}=3$ & 17 & 13 & 8.68 & 0.794 & 2.51 & 11.56 & 0.913 & 0.937 & 0.72 & $0.888 *$ & $0.2991 *$ \\
\hline $\mathrm{WW} 2, \mathrm{k}=3$ & 4 & 1 & 1 & 0 & 0 & 1 & 0 & $\mathrm{NaN}$ & 0.468 & $\mathrm{NaN}$ & $\mathrm{NaN}$ \\
\hline $\mathrm{WW} 1+2, \mathrm{k}=3(=\mathrm{WW} 1, \mathrm{k}=2)$ & 21 & 14 & 12.7 & 0.789 & 2.52 & 10.76 & 0.907 & 0.857 & 0.772 & $1.127^{*}$ & $0.3791 *$ \\
\hline $\mathrm{WW} 3, \mathrm{k}=3(=\mathrm{WW} 2, \mathrm{k}=2)$ & 18 & 8 & 5.15 & 1.021 & 1.53 & 2.95 & 0.66 & 0.535 & 0.6 & -0.106 & -0.0554 \\
\hline Total WW $(1+2+3)^{\mathrm{e}}$ & 39 & 22 & 7.79 & 1.184 & 2.75 & 10.07 & 0.901 & 0.617 & 0.772 & 1.455 & 0.5143 \\
\hline MEX1 & 12 & 12 & 12 & 0 & 2.48 & 12 & 0.917 & 1 & 0.793 & $0.9102 *$ & $0.32703 *$ \\
\hline $\mathrm{MEX} 1 \mathrm{a}=\mathrm{WW} 3$ & 6 & 6 & 6 & 0 & 1.79 & 6 & 0.833 & 1 & 0.511 & -0.0333 & -0.0346 \\
\hline $\mathrm{MEX} 2$ = WW2 & 37 & 29 & 10.9 & 0.936 & 3.25 & 21.7 & 0.954 & 0.84 & 0.614 & 0.0258 & 0.00886 \\
\hline MEX Total $(1+2)$ & 49 & 41 & 11.3 & 0.769 & 3.62 & 32 & 0.969 & 0.857 & 0.701 & 0.6743 & 0.22655 \\
\hline
\end{tabular}

a STRUCTURE = genetically distinct groups based on analysis using the software STRUCTURE.

b Number of isolates.

c Number of multilocus genotypes.

d Asterisks indicate populations characterized by significant linkage disequilibrium.

e Bold indicates results for the entire worldwide (WW) and Mexican (MEX) samples. 
determine which specific genotypes should not be introduced or further spread in any given region. For instance, group WW2 genotypes are common in Mexico, but they were absent in our sample from most of California, except for Christmas tree farms and manzanita stands in two counties in the foothills of the Sierra Nevada mountains. Conversely, the emergent invasive genotype MG18 is not present in Mexico, but it is dominant in California.
Likewise, its spread into Mexico from California should be prevented by well-designed regulations. An additional concern is that release of A1 and A2 genotypes into the wild could lead to sexual reproduction, thus accelerating the adaptive potential of this already invasive and aggressive pathogen.

Summary. Figure 5 is a schematic reconstruction of the recent history and movement of $P$. cinnamomi based on our results. In

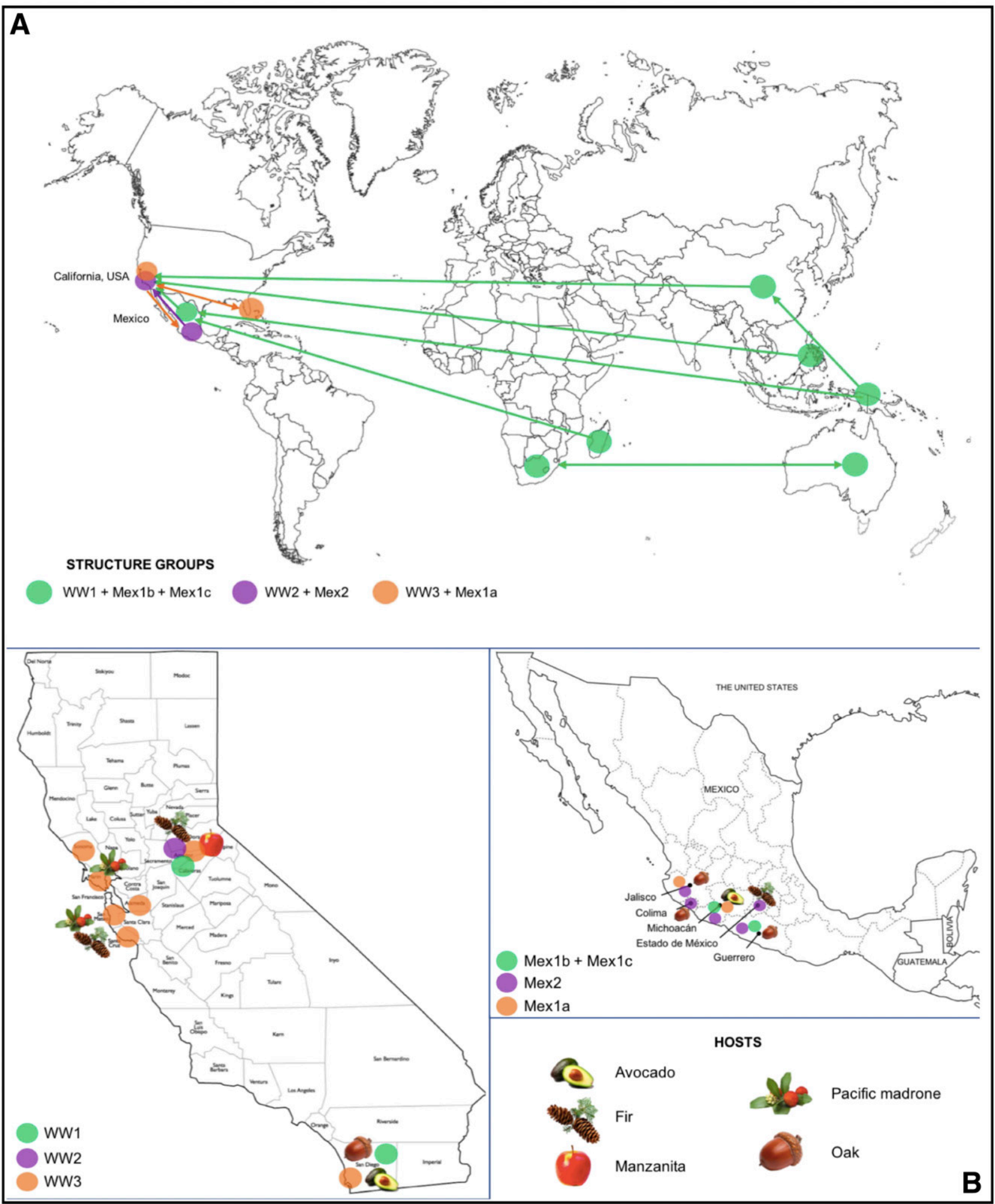

Fig. 5. A, Schematic reconstruction of the historical movement of Phytophthora cinnamomi based on the presence of identical or quasi-identical multilocus genotypes in different world regions. B, Recent cross-contamination between agricultural and wild hosts in California and Mexico inferred by tracking the presence of identical multilocus genotypes in agricultural commodities and in native flora in the same region. 
brief, from a native asexual population with mating type A1, individual genotypes became founders of populations associated with different commodities. These commodities were responsible for the worldwide movement of genotypes associated with them, as documented by the fact that identical or very similar genotypes were found in the same commodity but in distant locations of the world (Linde et al. 1999; Oudemans and Coffey 1991; Pagliaccia et al. 2013). During a relative early stage of the modern history of $P$. cinnamomi, cross-contamination among commodities occurred, as evidenced by the presence of identical genotypes in different agricultural commodities. Without excluding commodities that were not sampled in this study, four commodities have had a clearly important role in the long-distance movement of P. cinnamomi: avocado, ornamental plants, grapes, and, more recently, Christmas trees or conifer plant stock provided by nurseries to Christmas tree farms. Mexico appears to be an early recipient of this pathogen compared with California (especially of genotypes of group 2), which is more genotypically diversified and has a much broader distribution in Mexico than in California. These same commodities may have recently been responsible for the introduction of $P$. cinnamomi in wildland settings. Our California and Mexican analyses identified some likely sources for wild outbreaks. Genotypes from avocados appeared as the likely source of outbreaks responsible for the death of large numbers of oaks in several Mexican states (Tainter et al. 2000) and of oak infections in Southern California (Garbelotto et al. 2006). The bulk of the manzanita outbreak in California was caused by a single genotype in group 2 that likely arrived in California from Mexico through the trade of Douglas firs produced as Christmas trees. Direction of movement here was presumed based on the much greater abundance and diversity of group 2 genotypes in Mexico. The pathway of movement (i.e., through infected Douglas fir Christmas trees) was inferred based on a conversation with the owner of the infested Christmas tree farm in Mexico, who had a history of plant trading with California Christmas tree facilities (M. Garbelotto, personal communication). Although plausible, this hypothesis needs to be confirmed by a more widespread sampling of California infestations. One of the manzanita species affected, Arctostaphylos myrtifolia, is on the list of endangered plants in the United States (USDA 2017) and likely to become extinct because of the devastating effects of P. cinnamomi (Swiecki et al. 2003). A disease outbreak on highly prized Pacific madrones in the San Francisco Greater Bay Area (Rizzo and Fichtner 2009) was caused by a clearly invasive and recently emerged single genotype in group WW3 present on several commodities. Interestingly, even if group WW3 were present both in California and Mexico (where it was defined as group MEX1a), the invasive genotype in question was absent in Mexico, suggesting that its emergence was recent and occurred only in California.

$P$. cinnamomi has long been known to affect agricultural crops and wild populations of plants (Garbelotto et al. 2006; Zentmyer 1976); consequently, it is currently not regulated in the United States. However, this study uncovered the presence of emergent invasive genotypes strongly associated with three newly reported outbreaks on California oaks, manzanitas, and Pacific madrones (Garbelotto et al. 2006; Rizzo and Fichtner 2009; Swiecki et al. 2003). The discovery of emergent invasive genotypes warrants further research to determine whether significant phenotypic variability exists within $P$. cinnamomi and requires a different regulatory approach for different strains. Because of the recent results showing that invasive populations of pathogens can rapidly evolve and become strikingly different from their source populations (Garbelotto et al. 2015), the introduction of multiple genotypes from source populations may result in different disease outbreaks. Therefore, the need to prevent multiple introductions of the same pathogen may warrant changes in regulations worldwide and in international trading practices.

\section{ACKNOWLEDGMENTS}

We are thankful to Silvia Mascheretti for help with the analyses.

\section{LITERATURE CITED}

Agapow, P. M., and Burt, A. 2001. Indices of multilocus linkage disequilibrium. Mol. Ecol. Notes 1:101-102.

Arentz, F. 2017. Phytophthora cinnamomi A1: An ancient resident of New Guinea and Australia of Gondwanan origin? For. Pathol. 47:e12342.

Arentz, F., and Simpson, J. A. 1986. Distribution of Phytophthora cinnamomi in Papua New Guinea and notes on its origin. Trans. Br. Mycol. Soc. 87: 289-295.

Balci, Y., Long, R. P., Mansfield, M., Balser, D., and MacDonald, W. L. 2010. Involvement of Phytophthora species in white oak (Quercus alba) decline in southern Ohio. For. Pathol. 40:430-442.

Beever, R. E., Waipara, N. W., Ramsfield, T. D., Dick, M. A., and Horner, I. J. 2009. Kauri (Agathis australis) under threat from Phytophthora. Pages 74-85 in: Fourth Meeting of IUFRO Working Party S07.02.09 Phytophthoras in Forests and Natural Ecosystems. General Technical Report PSWGTR-221. E. M. Goheen and S. J.Frankel, eds. U.S. Department of Agriculture, Forest Service, Pacific Southwest Research Station, Monterey, USA.

Brasier, C. M. 1996. Phytophthora cinnamomi and oak decline in southern Europe. Environmental constraints including climate change. Ann. For. Sci. 53:347-358.

Brown, A. H. D., Feldman, M. W., and Nevo, E. 1980. Multilocus structure of natural populations of Hordeum spontaneum. Genetics 96:523-536.

Bruvo, R., Michiels, N. K., D’Souza, T. G., and Schulenburg, H. 2004. A simple method for the calculation of microsatellite genotype distances irrespective of ploidy level. Mol. Ecol. 13:2101-2106.

Chhatre, V. E., and Emerson, K. J. 2017. StrAuto: Automation and parallelization of STRUCTURE analysis. BMC Bioinformatics 18:192.

Croucher, P. J. P., Mascheretti, S., and Garbelotto, M. 2013. Combining field epidemiological information and genetic data to comprehensively reconstruct the invasion history and the microevolution of the sudden oak death agent Phytophthora ramorum (Stramenopila: Oomycetes) in California. Biol. Invasions 15:2281-2297.

Dehnen-Schmutz, K., Holdenrieder, O., Jeger, M. J., and Pautasso, M. 2010. Structural change in the international horticultural industry: Some implications for plant health. Sci. Hortic. (Amsterdam) 125:1-15.

Desprez-Loustau, M. L., Robin, C., Buée, M., Courtecuisse, R., Garbaye, J., Suffert, F., Sache, I., and Rizzo, D. 2007. The fungal dimension of biological invasion. Ecol. Evol. 22:472-480.

Dixon, D. M., McNeil, M. M., Cohen, M. L., Gellin, B. G., and La Montagne, J. R. 1996. Fungal infections: A growing threat. Public Health Rep. 111: 226-235.

Dobrowolski, M. P., Tommerup, I. C., Blakeman, H. D., and O'Brien, P. A. 2002. Non-Mendelian inheritance revealed in a genetic analysis of sexual progeny of Phytophthora cinnamomi with microsatellite markers. Fungal Genet. Biol. 35:197-212.

Dobrowolski, M. P., Tommerup, I. C., and O’Brien, P. A. 1998. Microsatellites in the mitochondrial genome of Phytophthora cinnamomi failed to provide highly polymorphic markers for population genetics. FEMS Microbiol. Lett. 163:243-248.

Dobrowolski, M. P., Tommerup, I. C., Shearer, B. L., and O’Brien, P. A. 2003. Three clonal lineages of Phytophthora cinnamomi in Australia revealed by microsatellites. Phytopathology 93:695-704.

Earl, D. A., and vonHoldt, B. M. 2011. STRUCTURE HARVESTER: A website and program for visualizing STRUCTURE output and implementing the Evanno method. Conserv. Genet. Resour. 4:359-361.

Eggers, J. E., Balci, Y., and MacDonald, W. L. 2012. Variation among Phytophthora cinnamomi isolates from oak forest soils in the eastern United States. Plant Dis. 96:1608-1614.

EPPO/CABI. 2011. Data sheets on Quarantine Pests. Phytophthora cinnamomi. https://gd.eppo.int/taxon/PHYTCN/documents

Erwin, D. C., and Ribeiro, O. K. 1996. Phytophthora Diseases Worldwide. American Phytopathological Society, St. Paul, MN.

Evanno, G., Regnaut, S., and Goudet, J. 2005. Detecting the number of clusters of individuals using the software STRUCTURE a simulation study. Mol. Ecol. 14:2611-2620.

Eyre, C. A., and Garbelotto, M. 2015. Detection, diversity, and population dynamics of waterborne Phytophthora ramorum populations. Phytopathology 105:57-68.

Fichtner, E. J., Rizzo, D. M., Swiecki, T. J., and Bernhardt, E. A. 2009. Emergence of Phytophthora cinnamomi in a sudden oak death-impacted forest. Pages 320-321 In: Proceeding of the sudden oak death fourth science symposium. General Technical Report PSW-GTR-229. S. Frankel, 
J. L.Kliejunas, and K.Palmieri, eds. U.S. Department of Agriculture, Forest Service, Pacific Southwest Research Station, Albany, USA.

French, A. M. 1989 California Plant Disease Host Index. Calif. Dept. Food Agric., Sacramento, CA.

Garbelotto, M. 2008. Molecular analyses to study invasions by forest pathogens: Examples from Mediterranean ecosystems. Phytopathol. Mediterr. 47: 183-203.

Garbelotto, M., Frankel, S. J., and Scanu, B. 2018. Soil- and waterborne Phytophthora species linked to recent outbreaks in Northern California restoration sites. Calif. Agric. 72:208-216.

Garbelotto, M., and Gonthier, P. 2013. Biology, epidemiology, and control of Heterobasidion species worldwide. Annu. Rev. Phytopathol. 51:39-59.

Garbelotto, M., Hüberli, D., and Shaw, D. 2006. First report on an infestation of Phytophthora cinnamomi in Natural oak woodlands of California and its different impact on two native oak species. Plant Dis. 90:685.

Garbelotto, M., and Pautasso, M. 2012. Impacts of exotic forest pathogens on Mediterranean ecosystems: Four case studies. Eur. J. Plant Pathol. 133: 101-116.

Garbelotto, M., Rocca, G. D., Osmundson, T., di Lonardo, V., and Danti, R. 2015. An increase in transmission-related traits and in phenotypic plasticity is documented during a fungal invasion. Ecosphere 6:1-16.

Gómez-Aparicio, L., Ibáñez, B., Serrano, M. S., de Vita, P., Avila, J. M., Perez-Ramos, I. M., Garcia, L. V., Sanchez, M. E., and Marañon, T. 2012. Spatial patterns of soil pathogens in declining Mediterranean forests: Implications for tree species regeneration. New Phytol. 194:1014-1024.

Griffin, G. J., Reaver, D., Osborne, C. K., and Yancey, M. M. 2009. Root recovery rates for Phytophthora cinnamomi and rate of symptom development from root rot on Abies fraseri trees over 7 years. For. Pathol. 39: 15-27.

Grünwald, N. J., Everhart, S. E., Knaus, B. J., and Kamvar, Z. N. 2017. Best practices for population genetic analyses. Phytopathology 107:1000-1010.

Grünwald, N. J., Goodwin, S. B., Milgroom, M. G., and Fry, W. E. 2003 Analysis of genotypic diversity data for populations of microorganisms. Phytopathology 93:738-746.

Hardham, A. R. 2005. Phytophthora cinnamomi. Mol. Plant Pathol. 6:589-604.

Hayden, K. J., St. Hardy, G. E., and Garbelotto, M. 2013. Oomycetes Diseases. Pages 519-545 in: Infectious Forests Diseases. P. Gonthier and G. Nicolotti, eds. CAB Publishing, London, UK

Hurlbert, S. H. 1971. The nonconcept of species diversity: a critique and alternative parameters. Ecology 52:577-586.

Ivors, K., Garbelotto, M., Vries, I. D., Ruyter-Spira, C., Hekkert, B. T., Rosenzweig, N., and Bonants, P. 2006. Microsatellite markers identify three lineages of Phytophthora ramorum in US nurseries, yet single lineages in US forest and European nursery populations. Mol. Ecol. 15:1493-1505.

Jakobsson, M., and Rosenberg, N. A. 2007. CLUMPP: A cluster matching and permutation program for dealing with label switching and multimodality in analysis of population structure. Bioinformatics 23:1801-1806.

Jung, T., Duran, A., Sanfuentes, E., Schena, L., Mosca, S., Fajardo, S., González, M., Bajonyi, J., Seress, D., Scanu, B., Cravador, S., Maia, C., and Horta Jung, M. 2017. Diversity of Phytophthora species in Valdivian rainforests and their association with severe dieback. Page 55 In: Proceeding of the eighth Meeting IUFRO Working Party 7-02-09 Phytophthora in Forests and Natural Ecosystems. Sapa, Vietnam.

Jung, T., Orlikowski, L., Henricot, B., Abad-Campos, P., Aday, A. G., Aguín Casal, O., Bakonyi, J., Cacciola, S. O., Cech, T., Chavarriaga, D., Corcobado, T., Cravador, A., Decourcelle, T., Denton, G., Diamandis, S., Dogmus-Lehtijärvi, H. T., Franceschini, A., Ginetti, B., Gree, S., Glavendekic, M., Hantula, J., Hartmann, G., Herrero, M., Ivic, D., Horta Jung, M., Lilja, A., Kramarets, V., Lyubenova, A., Machado, H., Magnano di San Lio, G., Mansilla Vázquez, P. J., Marçais, B., Matsiakh, I., Milenkovic, I., Moricca, S., Nagy, Z. A., Nechwatal, J., Olsson, C., Oszako, T., Pane, A., Paplomatas, E. J., Pintos Varela, C., Prospero, S., Rial Martínez, C., Rigling, D., Robin, C., Rytkönen, A., Sánchez, M. E., Sanz Ros, A. V., Scanu, B., Schlenzig, A., Shumacher, J., Slavov, S., Solla, A., Sousa, E., Stenlid, J., Talgo, V., Tomic, Z., Tsopelas, P., Vannini, A., Vettraino, A. M., Wenneker, M., Woodward, S., and Pérez-Sierra, S. 2016. Widespread Phytophthora infestations in European nurseries put forest, semi-natural and horticultural ecosystems at high risk of Phytophthora diseases. For. Pathol. 46:134-163.

Kamvar, Z. N., Tabima, J. F., Grünwald, N. J. 2014. Poppr: An R package for genetic analysis of populations with clonal, partially clonal, and/or sexual reproduction. PeerJ 2:e281.

Kasuga, T., Bui, M., Bernhardt, E., Swiecki, T., Aram, K., Cano, L., Webber, J., Brasier, C., Press, C., Grunwald, N., Rizzo, D., and Garbelotto, M. 2016. Host-induced aneuploidy and phenotypic diversification in the sudden oak death pathogen Phytophthora ramorum. BMC Genomics 17:385.

Linde, C., Drenth, A., Kemp, G. H. J., Wingfield, M. J., and von Broembsen, S. L. 1997. Population structure of Phytophthora cinnamomi in South Africa. Phytopathology 87:822-827.
Linde, C., Drenth, A., and Wingfield, M. J. 1999. Gene and genotypic diversity of Phytophthora cinnamomi in South Africa and Australia revealed by DNA polymorphisms. Eur. J. Plant Pathol. 105:667-680.

Lowe, S. J., Browne, M., and Boudjelas, S. 2000. 100 of the world's worst invasive alien species. IUCN/SSC Invasive Species Specialist Group, Auckland. http://www.issg.org/pdf/publications/worst_100/english_100_worst.pdf

Mascheretti, S., Croucher, P. J. P., Kozanitas, M., Baker, L., and Garbelotto, M. 2009. Genetic epidemiology of the sudden oak death pathogen Phytophthora ramorum in California. Mol. Ecol. 18:4577-4590.

Mascheretti, S., Croucher, P. J. P., Vettraino, A., Prospero, S., and Garbelotto, M. 2008. Reconstruction of the sudden oak death epidemic in California thought microsatellite analysis of the pathogen Phytophthora ramorum. Mol. Ecol. 17:2755-2768.

McConnell, M. E., and Balci, Y. 2014. Phytophthora cinnamomi as a contributor to White Oak decline in Mid-Atlantic Unites States forests. Plant Dis. 98:319-327.

McKeever, K. M., and Chastagner, G. A. 2016. A survey of Phytophthora spp. associated with Abies in U.S. Christmas tree farms. Plant Dis. 100:1161-1169.

Meirmans, P. G., and Van Tienderen, P. H. 2004. GENOTYPE and GENODIVE: Two programs for the analysis of genetic diversity of asexual organisms. Mol. Ecol. Notes 4:792-794.

Nagle, A. M., Long, R. P., Madden, L. V., and Bonello, P. 2010. Association of Phytophthora cinnamomi with white oak decline in southern Ohio. Plant Dis. 94:1026-1034.

Nei, M. 1978. Estimation of average heterozygosity and genetic distance from a small number of individuals. Genetics 89:583-590.

Old, K. M., Dudzinski, M. J., and Bell, C. J. 1988. Isozyme variability in field populations of Phytophthora cinnamomi in Australia. Aust. J. Bot. 36: $355-360$

Old, K. M., Moran, G. F., and Bell, J. C. 1984. Isozyme variability among isolates of Phytophthora cinnamomi from Australia and Papua New Guinea. Can. J. Bot. 62:2016-2022.

Oudemans, P., and Coffey, M. D. 1991. Isozyme comparison within and among worldwide sources of three morphologically distinct species of Phytophthora. Mycol. Res. 95:19-30.

Paetkau, D., and Strobeck, C. 1994. Microsatellite analysis of genetic variation in black bear populations. Mol. Ecol. 3:489-495.

Pagliaccia, D., Pond, E., McKee, B., and Douhan, G. W. 2013. Population genetic structure of Phytophthora cinnamomi associated with avocado in California and the discovery of a potentially recent introduction of a new clonal lineage. Phytopathology 103:91-97.

Parks, J. C., and Werth, C. R. 1993. A study of spatial features of clones in a population of bracken fern, Pteridium aquilinum (Dennstaedtiaceae). Am. J. Bot. 80:537-544.

Pritchard, J. K., Stephens, M., and Donnelly, P. 2000. Inference of population structure using multilocus genotype data. Genetics 155:945-959.

Quynh, D. N., Nam, P. Q., Ha, N. M., and Thu, P. Q. 2017. First report of Phytophthora cinnamomi on Cinnamomum cassia in Vietnam. Pages 34 in: Proceeding of the eighth Meeting IUFRO Working Party 7-02-09 Phytophthora in Forests and Natural Ecosystems. Sapa, Vietnam.

Rands, R. D. 1922. Stripe canker of cinnamon caused by Phytophthora cinnamomi n. sp. Mededelingen van het Instituut voor Plantenziekten 54.

Rizzo, D. M., and Fichtner, E. 2009. Phytophthora in Forests and Natural Ecosystems of the Americas. Pages 35-44 in: Fourth Meeting of IUFRO Working Party S07.02.09 Phytophthoras in Forests and Natural Ecosystems: General Technical Report PSW-GTR-221. E. M.Goheen, and S. J.Frankel, eds. Department of Agriculture, Forest Service, Pacific Southwest Research Station, Monterey, USA.

Rosenberg, N. A. 2004. DISTRUCT: Aprogram for the graphical display of population structure. Mol. Ecol. Notes 4:137-138.

Sánchez, M. E., Caetano, P., Ferraz, J., and Trapero, A. 2002. Phytophthora disease of Quercus ilex in south-western Spain. For. Pathol. 32:5-18.

Santini, A., Ghelardini, L., Pace, C. D., Desprez-Loustau, M. L., Capretti, P., Chandelier, A., Cech, T., Chira, D., Diamandis, S., Gaitniekis, T., Hantula, J., Holdenrieder, O., Jankosky, L., Jung, T., Jurc, D., Kirisits, T., Kunca, A., Lygis, V., Malecka, M., Marcais, B., Schmitz, S., Schumacher, J., Solheim, H., Solla, A., Szabò, I., Tsopelas, P., Vannini, A., Vettraino, A. M., Webber, J., Woodward, S., and Stenlid, J. 2013. Biogeographical patterns and determinants of invasion by forest pathogens in Europe. New Phytol. 197: $238-250$

Shannon, C. E. 2001. A mathematical theory of communication. ACM SIGMOBILE. Mob. Comput. Commun. Rev. 5:3-55.

Shearer, B. L., Crane, C. E., and Cochrane, A. 2004. Quantification of the susceptibility of the native flora of the South-West Botanical Province, Western Australia, to Phytophthora cinnamomi. Aust. J. Bot. $52: 435-443$

Simpson, E. H. 1949. Measurement of diversity. Nature 163:688

Smith, J. M., Smith, N. H., O’Rourke, M., and Spratt, B. G. 1993. How clonal are bacteria? P. Natl. Acad. Sci. 90:4384-4388 
Stoddart, J. A., and Taylor, J. F. 1988. Genotypic diversity: Estimation and prediction in samples. Genetics 118:705-711.

Swiecki, T. J., Bernhardt, E. A., and Garbelotto, M. 2003. First report of root and crown rot caused by Phytophthora cinnamomi affecting native stands of Arctostaphylos myrtifolia and A. viscida in California. Plant Dis. 87:1395.

Tainter, F. H. 1997. Littleleaf disease. Pages 4-6 in: Compendium of Conifer Diseases. E. M. Hansen and K. J. Lewis, eds. American Phytopathological Society, St. Paul, MN.

Tainter, F. H., O'Brien, J. G., Hernández, A., Orozco, F., and Rebolledo, O. 2000. Phytophthora cinnamomi as a cause of oak mortality in the state of Colima, Mexico. Plant Dis. 84:394-398.

USDA. 2017. Threatened and Endangered Information: Arctostaphylos myrtifolia Parry. https://plants.usda.gov/core/profile?symbol=ARMY

Vannini, A., and Vettraino, A. M. 2001. Ink disease in chestnuts: Impact on the European chestnut. For. Snow Landsc. Res. 76:345-350.
Vettraino, A. M., Natili, G., Anselmi, N., and Vannini, A. 2001. Recovery and pathogenicity of Phytophthora species associated with a resurgence of ink disease in Castanea sativa in Italy. Plant Pathol. 50:90-96.

Waits, L. P., Luikart, G., and Taberlet, P. 2001. Estimating the probability of identity among genotypes in natural populations: Cautions and guidelines. Mol. Ecol. 10:249-256

Wingfield, M. J., Slippers, B., Roux, J., and Wingfield, B. D. 2001. Worldwide movement of exotic forest fungi, especially in the tropics and the southern hemisphere. Bioscience 51:134-140.

Zentmyer, G. A. 1976. Distribution of the Al mating type of Phytophthora cinnamomi. Phytopathology 66:701-703.

Zentmyer, G. A. 1983. The world of Phytophthora. Pages 1-8 in: Phytophthora: Its Biology, Taxonomy, Ecology and Pathology. D. C. Erwin, S. Barnicki-García, and T. Hsing-tsuen, eds.American Phytopathological Society, St. Paul, MN.

Zentmyer, G. A. 1988. Origin and distribution of four species of Phytophthora. Trans. Br. Mycol. Soc. 91:367-378. 